\title{
Assessment of Managed Aquifer Recharge at Sand Hollow Reservoir, Washington County, Utah, Updated to Conditions through 2007
}

Prepared in cooperation with the Washington County Water Conservancy District

Scientific Investigations Report 2009-5050

U.S. Department of the Interior U.S. Geological Survey 
Cover: Photograph of Sand Hollow Reservoir and Navajo Sandstone outcrop near the boat ramp, taken on May 5, 2008. 


\section{Assessment of Managed Aquifer Recharge at Sand Hollow Reservoir, Washington County, Utah, Updated to Conditions through 2007}

By Victor M. Heilweil, Gema Ortiz, and David D. Susong

Prepared in cooperation with the Washington County Water Conservancy District

Scientific Investigations Report 2009-5050 


\title{
U.S. Department of the Interior \\ KEN SALAZAR, Secretary
}

\author{
U.S. Geological Survey \\ Suzette M. Kimball, Acting Director
}

U.S. Geological Survey, Reston, Virginia: 2009

For product and ordering information:

World Wide Web: http://www.usgs.gov/pubprod

Telephone: 1-888-ASK-USGS

For more information on the USGS--the Federal source for science about the Earth, its natural and living resources, natural hazards, and the environment:

World Wide Web: http://www.usgs.gov

Telephone: 1-888-ASK-USGS

Any use of trade, product, or firm names is for descriptive purposes only and does not imply endorsement by the U.S. Government.

Although this report is in the public domain, permission must be secured from the individual copyright owners to reproduce any copyrighted materials contained within this report.

Suggested citation:

Heilweil, V.M., Ortiz, Gema, and Susong, D.D., 2009, Assessment of managed aquifer recharge at Sand Hollow Reservoir, Washington County, Utah, updated to conditions through 2007: U.S. Geological Survey Scientific Investigations Report 2009-5050, 20 p.; Available at http://pubs.usgs.gov/sir/2009/5050. 


\section{Contents}

Abstract
Introduction
Data-Collection Methods and Results
Water-Level Data
Water-Quality Data
Reteorology and Precipitation Data
$\quad$ Calculation of Recharge from Sand Hollow Reservoir
$\quad$ Surface-Water Inflow and Outflow to Sand Hollow Reservoir
$\quad$ Estimated Managed Aquifer Recharge

\section{Figures}

1 Map showing location of the Sand Hollow study area, Washington County, Utah .... 2

2. Map showing location of wells, the weather station, and the reservoir sampling site in Sand Hollow, Utah.

3. Graph showing relation between water level in selected wells and reservoir altitude, Sand Hollow, Utah, 1995-2007

4. Graph showing total dissolved-gas pressure in ground water from selected monitoring wells in Sand Hollow, Utah.................................................................... 9

5. Graph showing specific conductance of reservoir water and ground water from selected monitoring wells in Sand Hollow, Utah

6. Graph showing chloride/bromide ratios of reservoir water and ground water from selected monitoring wells in Sand Hollow, Utah 10

7. Graph showing monthly precipitation at Sand Hollow, Utah, January 1998 through December 2007

8. Graph showing daily water temperature at various depths in Sand Hollow Reservoir, Utah, January 2003 through December 2007

9. Graph showing monthly estimated evaporation, estimated ground-water recharge, and reservoir altitude, Sand Hollow Reservoir, Utah, March 2002 through December 2007

10. Graph showing monthly estimated ground-water recharge rate beneath Sand Hollow Reservoir, Utah, June 2002 through December 2007

11. Graph showing annual inflow, estimated evaporation, and estimated groundwater recharge, Sand Hollow Reservoir, Utah, 2002-07 


\section{Tables}

1. Selected physical properties and concentration of chemical constituents in ground- and surface-water samples collected from selected sites in Sand Hollow, Utah

2. Reservoir data and estimated evaporation and ground-water recharge at Sand Hollow, Utah, 2002-07. 


\section{Conversion Factors, Datums, and Abbreviated Water-Quality Units}

\begin{tabular}{lcl}
\hline Multiply & By & To obtain \\
\hline inch (in.) & Length & \\
foot (ft) & 2.54 & centimeter $(\mathrm{cm})$ \\
mile (mi) & 0.3048 & meter (m) \\
& 1.609 & kilometer $(\mathrm{km})$ \\
\hline acre & Area & \\
acre & 4,047 & square meter $\left(\mathrm{m}^{2}\right)$ \\
square inch (in $\left.{ }^{2}\right)$ & 0.004047 & square kilometer $\left(\mathrm{km}^{2}\right)$ \\
square mile (mi $\left.{ }^{2}\right)$ & 6.452 & square centimeter $\left(\mathrm{cm}^{2}\right)$ \\
\hline & 2.590 & square kilometer $\left(\mathrm{km}^{2}\right)$ \\
\hline acre-foot (acre-ft) & Volume & \\
\hline & 1,233 & cubic meter $\left(\mathrm{m}^{3}\right)$ \\
\hline acre-foot per year (acre-ft/yr) & Flow rate & \\
foot per day (ft/d) & 0.0571 & cubic meter per second $\left(\mathrm{m}^{3} / \mathrm{s}\right)$ \\
\hline
\end{tabular}

Temperature in degrees Celsius $\left({ }^{\circ} \mathrm{C}\right)$ may be converted to degrees Fahrenheit $\left({ }^{\circ} \mathrm{F}\right)$ as follows:

$$
{ }^{\circ} \mathrm{F}=\left(1.8 x^{\circ} \mathrm{C}\right)+32 \text {. }
$$

Temperature in degrees Fahrenheit $\left({ }^{\circ} \mathrm{F}\right)$ may be converted to degrees Celsius $\left({ }^{\circ} \mathrm{C}\right)$ as follows:

$$
{ }^{\circ} \mathrm{C}=\left({ }^{\circ} \mathrm{F}-32\right) / 1.8 \text {. }
$$

Vertical coordinate information is referenced to the North American Vertical Datum of 1988 (NAVD 88); horizontal coordinate information is referenced to the North American Datum of 1983 (NAD 83). Altitude, as used in this report, refers to distance above the vertical datum.

Specific conductance is given in microsiemens per centimeter at 25 degrees Celsius $(\mu \mathrm{S} / \mathrm{cm}$ at $25^{\circ} \mathrm{C}$ ). Total dissolved-gas pressure is reported in millimeters of mercury $(\mathrm{mm} \mathrm{Hg})$, where 760 $\mathrm{mm} \mathrm{Hg}$ equals one atmosphere. Concentrations of chemical constituents in water are reported either in milligrams per liter (mg/L) or micrograms per liter ( $\mu \mathrm{g} / \mathrm{L})$. Stable-isotope concentration is reported as per mil, which is equivalent to parts per thousand. 


\title{
Assessment of Managed Aquifer Recharge at Sand Hollow Reservoir, Washington County, Utah, Updated to Conditions through 2007
}

\author{
By Victor M. Heilweil, Gema Ortiz, and David D. Susong
}

\section{Abstract}

Sand Hollow Reservoir in Washington County, Utah, was completed in March 2002 and is operated primarily as an aquifer storage and recovery project by the Washington County Water Conservancy District (WCWCD). Since its inception in 2002 through 2007, surface-water diversions of about 126,000 acre-feet to Sand Hollow Reservoir have resulted in a generally rising reservoir stage and surface area. Large volumes of runoff during spring 2005-06 allowed the WCWCD to fill the reservoir to a total storage capacity of more than 50,000 acre-feet, with a corresponding surface area of about 1,300 acres and reservoir stage of about 3,060 feet during 2006. During 2007, reservoir stage generally decreased to about 3,040 feet with a surface-water storage volume of about 30,000 acre-feet. Water temperature in the reservoir shows large seasonal variation and has ranged from about 3 to $30^{\circ} \mathrm{C}$ from 2003 through 2007. Except for anomalously high recharge rates during the first year when the vadose zone beneath the reservoir was becoming saturated, estimated ground-water recharge rates have ranged from 0.01 to 0.09 feet per day. Estimated recharge volumes have ranged from about 200 to 3,500 acre-feet per month from March 2002 through December 2007. Total ground-water recharge during the same period is estimated to have been about 69,000 acre-feet. Estimated evaporation rates have varied from 0.04 to 0.97 feet per month, resulting in evaporation losses of 20 to 1,200 acre-feet per month. Total evaporation from March 2002 through December 2007 is estimated to have been about 25,000 acre-feet. Results of water-quality sampling at monitoring wells indicate that by 2007, managed aquifer recharge had arrived at sites 37 and 36, located 60 and 160 feet from the reservoir, respectively. However, different peak arrival dates for specific conductance, chloride, chloride/ bromide ratios, dissolved oxygen, and total dissolved-gas pressures at each monitoring well indicate the complicated nature of interpreting the arrival of managed aquifer recharge water and estimating ground-water travel times. Additional tracers of managed aquifer recharge currently are being considered for further investigation.

\section{Introduction}

Sand Hollow Reservoir in Washington County, Utah, (fig. 1) was constructed in 2002 to provide surface-water storage and recharge to the underlying Navajo Sandstone. The reservoir is an off-channel facility that receives water diverted from the Virgin River near the town of Virgin, Utah. Previous reports (Heilweil and others, 2005; Heilweil and Susong, 2007) document pre-reservoir ground-water conditions prior to March 2002 and post-reservoir ground-water conditions, water budgets, and estimates of ground-water recharge from the reservoir from March 2002 through August 2006. These reports also contain completion information on the wells within Sand Hollow and historical water-quality and precipitation data.

The purpose of this report is to present recent data (water levels, meteorology, reservoir-water temperatures, selected chemical constituents of ground water and surface water) and to estimate ground-water recharge to the Navajo Sandstone underlying the reservoir through December 2007. This study is a cooperative effort by the Washington County Water Conservancy District (WCWCD) and the U.S. Geological Survey (USGS). Support for this work was provided by both the USGS and the WCWCD.

Sand Hollow is a $20 \mathrm{mi}^{2}$ basin located in the southeastern part of Washington County, Utah, about 10 mi northeast of St. George, Utah (fig. 1). It is part of the Virgin River drainage area of the Lower Colorado River Basin and the upper Mohave Desert ecosystem. Altitude ranges from 3,000 to 5,000 ft. Sand Hollow primarily is underlain by Navajo Sandstone that either is exposed at the surface or covered by a veneer of soil or surface-flood basalts (Hurlow, 1998). The stratigraphic thickness of the Navajo Sandstone ranges from a few hundred to more than $1,200 \mathrm{ft}$. 


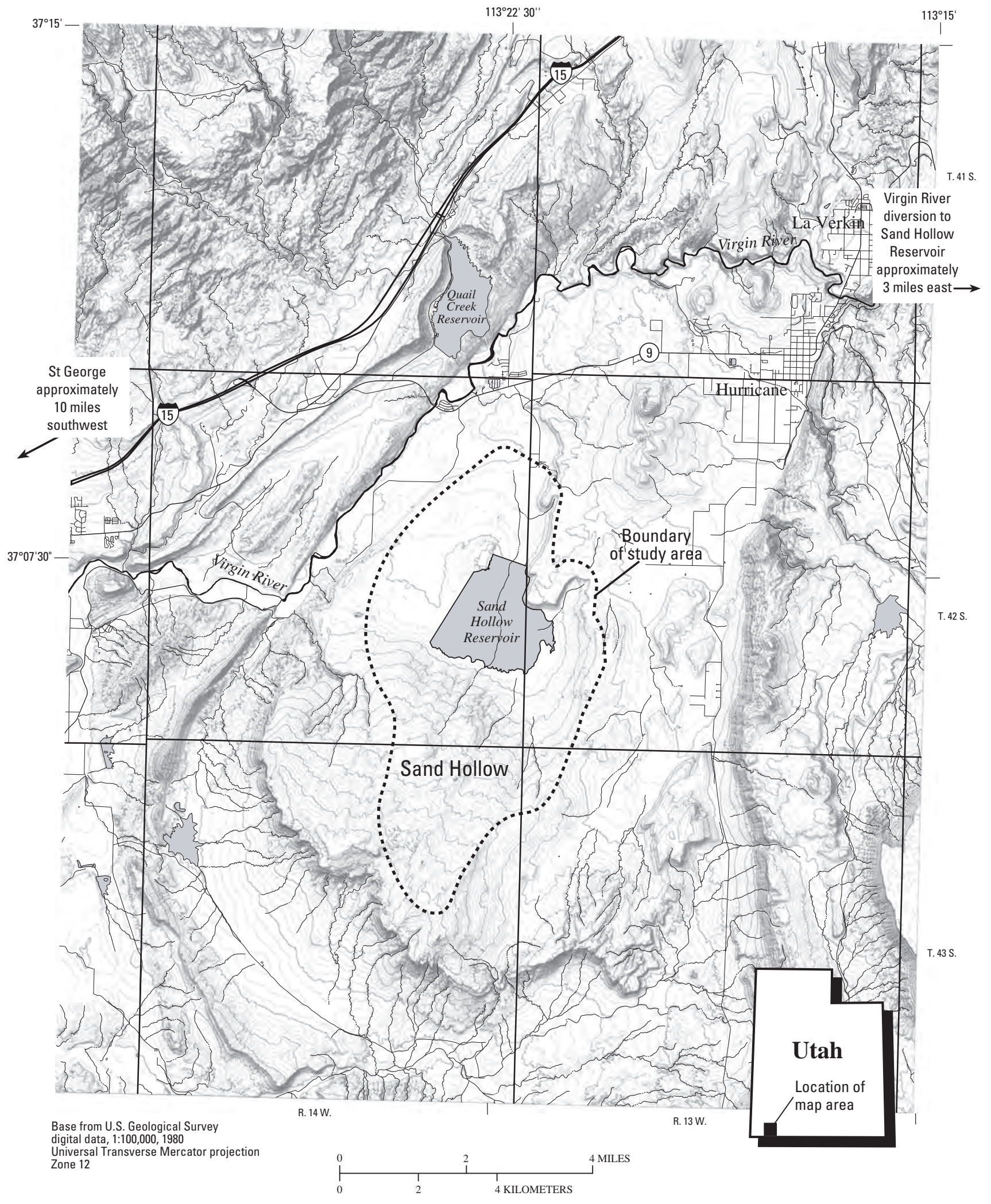

Figure 1. Location of the Sand Hollow study area, Washington County, Utah. 


\section{Data-Collection Methods and Results}

Data-collection methods are described in Heilweil and others (2005) and briefly summarized in the following sections.

\section{Water-Level Data}

Water levels measured in a monitoring-well network surrounding Sand Hollow Reservoir are used to document changes in the potentiometric surface as the reservoir fills and recharge occurs beneath that surface. The WCWCD measures water levels monthly at the reservoir and in the surrounding 15 monitoring wells (fig. 2). Wells measured monthly by the WCWCD have check measurements for quality assurance done by the USGS. In addition, a pressure transducer installed by the WCWCD in the reservoir along the North Dam records daily reservoir stage (January 2005 to present). Because there have been sporadic reliability issues with the quality of data from this transducer, occasional measurements also have been recorded at the boat ramp by WCWCD personnel. From 2005 through 2007, daily reservoir altitude has been interpolated using these boat ramp measurements, with trend confirmation from the transducer data.

Relations between recent (September 2006 through December 2007) and previously reported (1995-2006; Heilweil and others, 2005; Heilweil and Susong, 2007) waterlevel altitudes in selected wells and the reservoir are shown in figure 3 . The altitude of the water table in the surrounding 15 monitoring wells during December 2007 ranged from 2,908 to 3,038 ft (6 to $76 \mathrm{ft}$ below land surface and 6 to $136 \mathrm{ft}$ below reservoir stage, respectively). From September 2006 through December 2007, water-level trends varied among sites. Levels rose by more than $10 \mathrm{ft}$ at site 33 (west of the reservoir) and site 47 (south of the reservoir), yet declined by more than $10 \mathrm{ft}$ at two sites closer to the reservoir: site 5 (east of the reservoir) and site 9 (north of the reservoir). The rising water levels farther from the reservoir are part of the long-term water-table response to managed aquifer recharge, while the declines near the reservoir were a short-term response to the 16-ft decline in reservoir altitude between May 2006 and December 2007. The reservoir surface rose from an altitude of about 3,000 ft in March 2002 to a maximum altitude of about 3,060 ft in May 2006 and then receded to 3,044 ft in December 2007.

\section{Water-Quality Data}

Field-parameter measurements and chemical analysis of water samples from the reservoir and surrounding monitoring wells were used to evaluate changes in water quality and to assess the movement of managed aquifer recharge from the reservoir through the Navajo Sandstone aquifer. Field parameters were measured and water-quality samples were collected for laboratory chemical analysis from eight monitoring wells and Sand Hollow Reservoir during February 2007 (fig. 2). Water-quality sampling methods previously were described in Heilweil and others (2005) and Heilweil and Susong (2007). Three casing volumes were purged from each monitoring well prior to sample collection. Laboratory water-quality analysis included arsenic, bromide, chloride, deuterium, and oxygen-18. Field parameters were measured with a multi-parameter sonde at the bottom of each 2-in. monitoring well adjacent to the well screen and in the reservoir at a depth of 2 to $8 \mathrm{ft}$ at the boat ramp near site 37. Field parameters included water temperature, specific conductance, $\mathrm{pH}$, dissolved oxygen, and total dissolved gas pressure. The multi-parameter sonde was too large to enter the 1 -in. wells (sites 8, 32, 33, and 34); therefore, only occasional dissolved-oxygen measurements from these wells were made with a flow-through chamber; no total dissolved gas pressure measurements were made at these sites.

Arsenic is being monitored in ground water at Sand Hollow because changing oxidation and $\mathrm{pH}$ conditions at other managed aquifer recharge sites often has caused arsenic mobilization and has resulted in ground-water concentrations that exceed U.S. Environmental Protection Agency (EPA) drinking-water standards (Arthur and others, 2002). Elevated dissolved oxygen of up to three times atmospherically equilibrated concentrations (discussed below) have been measured in ground water near Sand Hollow Reservoir. Except for site 28, however, arsenic concentrations in water from the monitoring wells at Sand Hollow remained near or below the EPA $10 \mu \mathrm{g} / \mathrm{L}$ standard for drinking water (ranging from 1.9 to $13.3 \mu \mathrm{g} / \mathrm{L}$; table 1). Production wells in Sand Hollow were not sampled for arsenic during this study and there is no indication that water from these wells exceeds the EPA drinking-water standard. Arsenic concentrations in ground water from the 2-in. monitoring wells nearest the reservoir (sites 9, 36, and 37) all show an increase in arsenic after the inception of the reservoir, followed by a decrease of concentrations similar to or less than pre-reservoir conditions. It is hypothesized that the rise in arsenic concentrations is caused by arsenic mobilization associated with increased dissolved oxygen in the aquifer. The subsequent decline may be attributed to the replacement of natural ground water by low arsenic reservoir water; since its inception in 2002, arsenic concentrations in the reservoir water have been less than $3 \mu \mathrm{g} / \mathrm{L}$ and were $1.8 \mu \mathrm{g} / \mathrm{L}$ in February 2007. For example, arsenic concentrations at site 37 (60 ft from the reservoir) increased from $9.4 \mu \mathrm{g} / \mathrm{L}$ in 2001 to 12.0 $\mu \mathrm{g} / \mathrm{L}$ in 2002 , followed by a decrease to $6.2 \mu \mathrm{g} / \mathrm{L}$ in 2007 . At site 36 (160 ft from the reservoir), arsenic concentrations increased from $7.3 \mu \mathrm{g} / \mathrm{L}$ in 2002 to $17.0 \mu \mathrm{g} / \mathrm{L}$ in 2005 , and then decreased to $8.7 \mu \mathrm{g} / \mathrm{L}$ in 2007 . At site $9(1,000 \mathrm{ft}$ from the reservoir), arsenic concentrations increased from $2.0 \mu \mathrm{g} / \mathrm{L}$ in 2002 to $3.8 \mu \mathrm{g} / \mathrm{L}$ in 2005 , then decreased to $1.9 \mu \mathrm{g} / \mathrm{L}$ in 2007 .

The high concentration of arsenic at site 28 is considered to be a unique situation. This monitoring well, which is drilled into the shallow sandstone just below the North Dam, is screened from 15 to $25 \mathrm{ft}$ below land surface and initially 


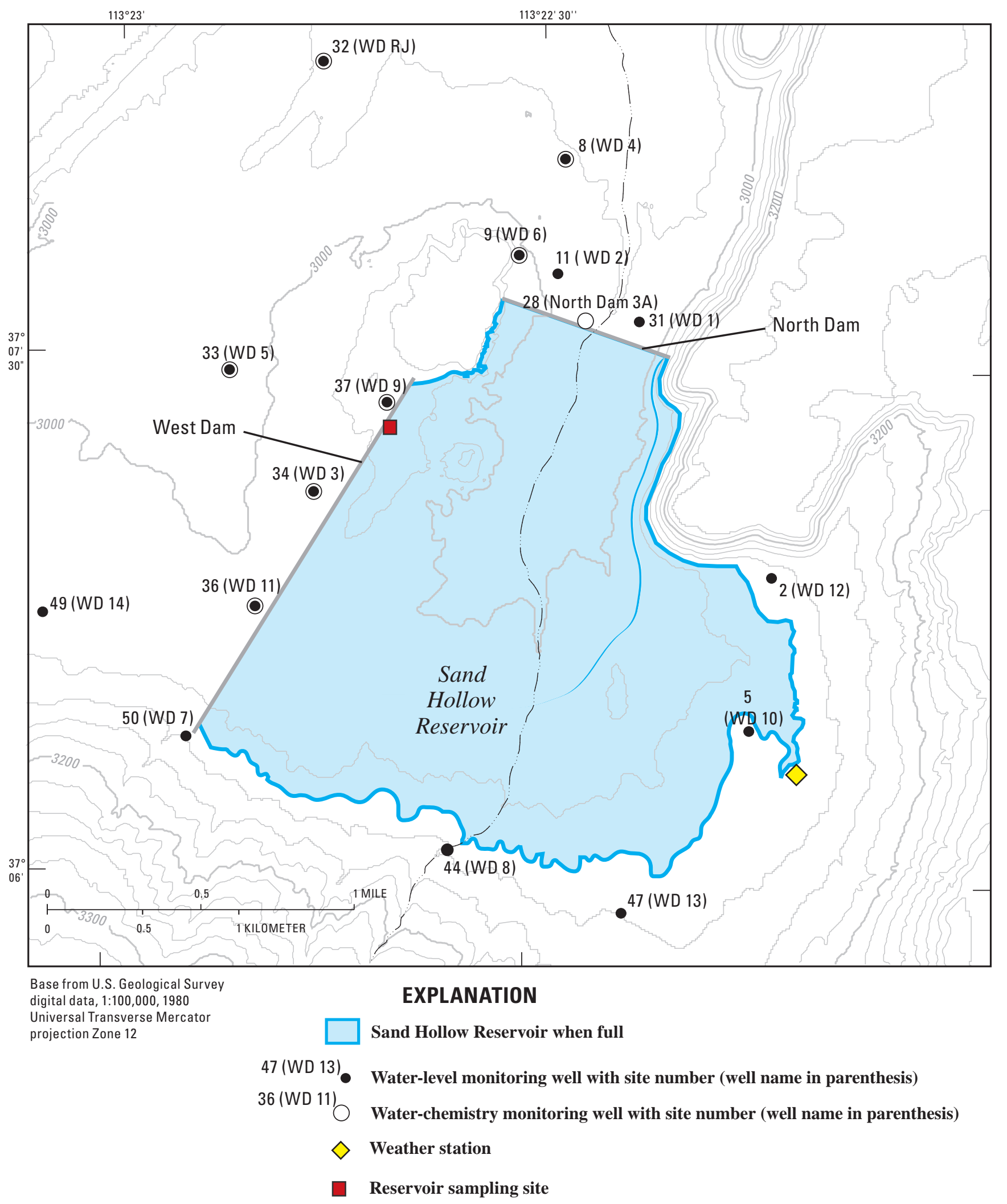

Figure 2. Location of wells, the weather station, and the reservoir sampling site in Sand Hollow, Utah. 


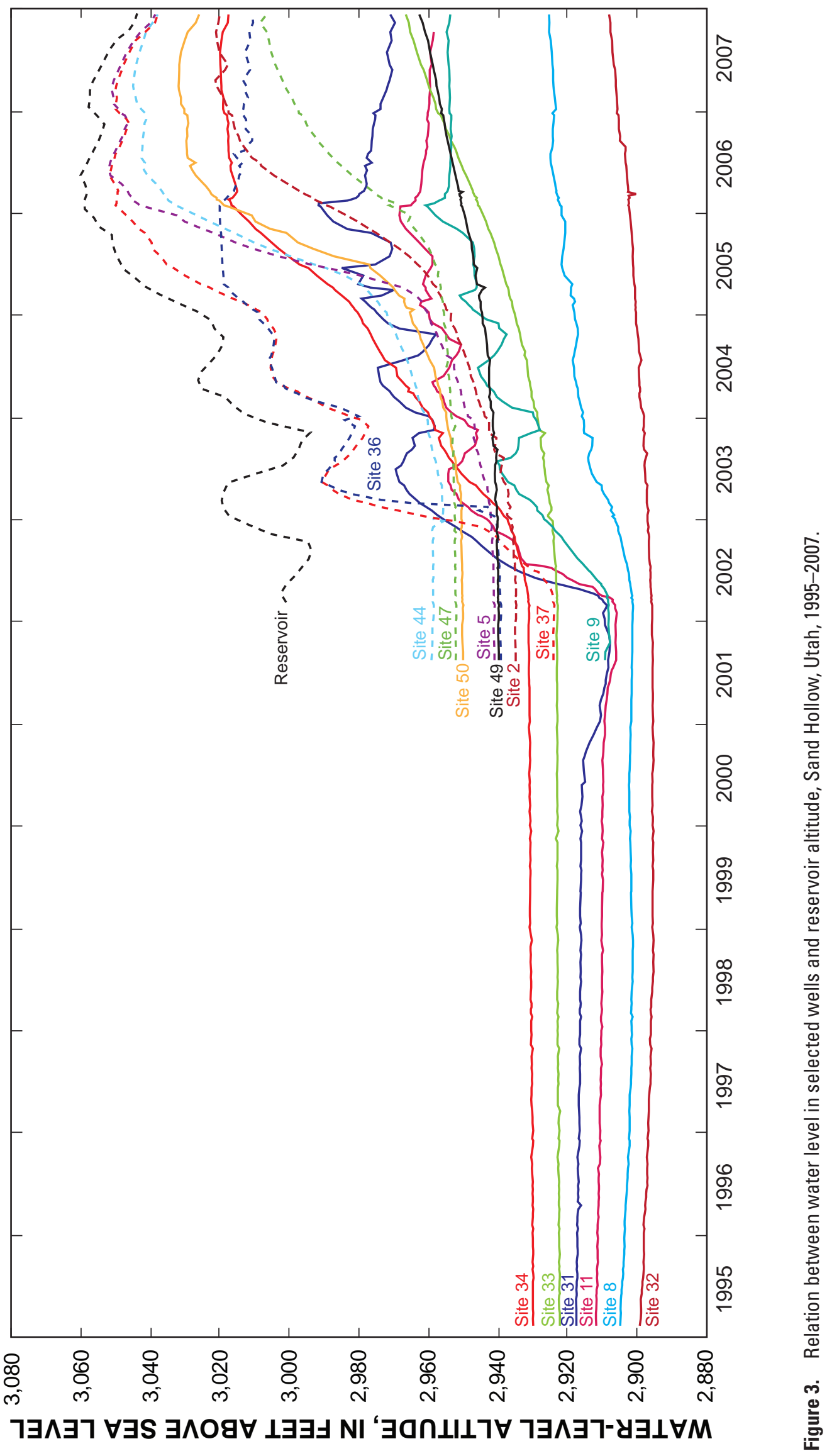


Table 1. Selected physical properties and concentration of chemical constituents in ground- and surface-water samples collected from selected sites in Sand Hollow, Utah.

[Site number: Refer to figure 2 and table 1 of Heilweil and others $(2005) ;{ }^{\circ} \mathrm{C}$, degrees Celsius; $\mu \mathrm{S} / \mathrm{cm}$, microsiemens per centimeter at 25 degrees Celsius; mg/L, milligrams per liter; mm, millimeters; $\mu \mathrm{g} / \mathrm{L}$, micrograms per liter; per mil, per thousand; —, no data; >, greater than]

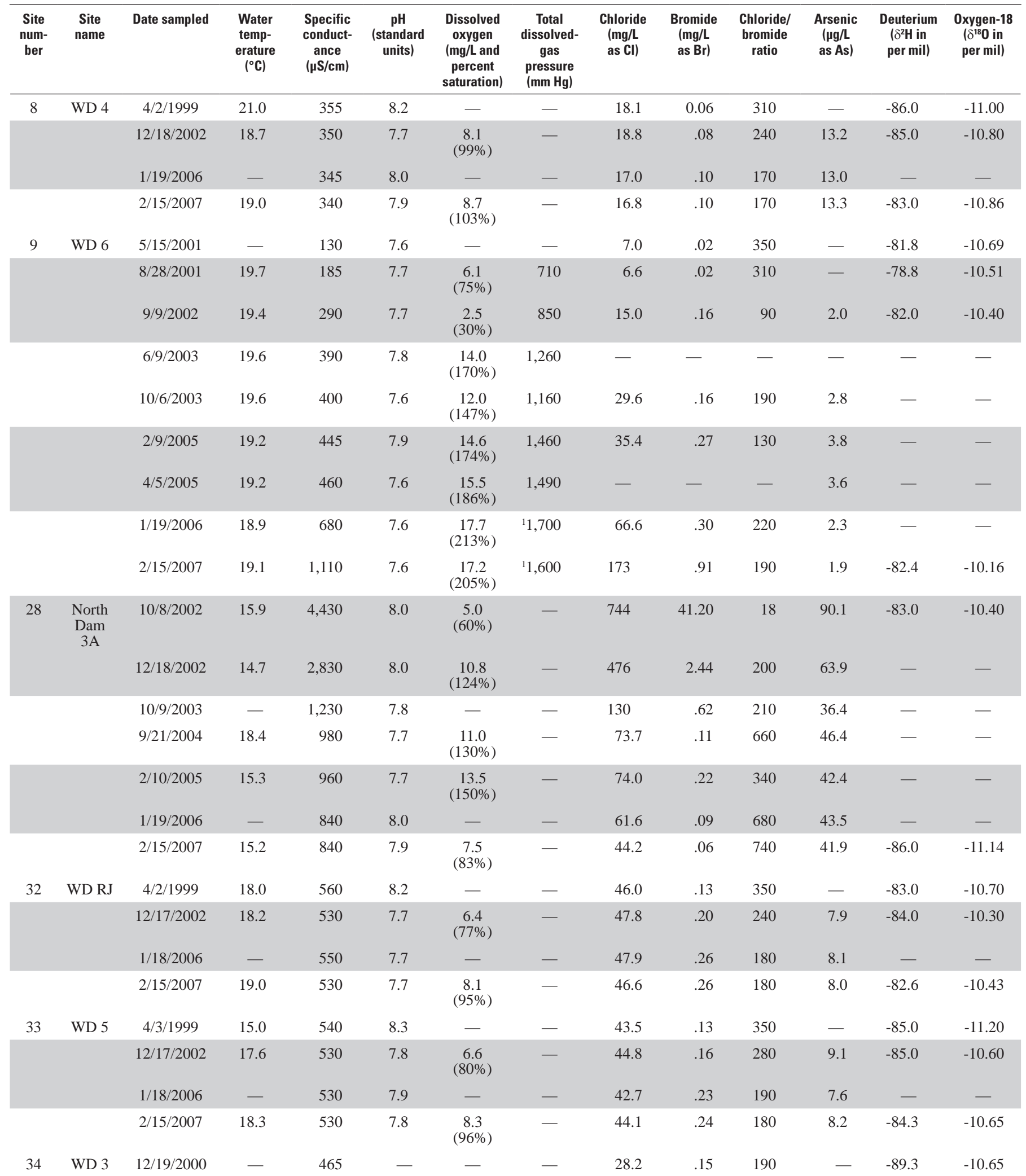


Table 1. Selected physical properties and concentration of chemical constituents in ground- and surface-water samples collected from selected sites in Sand Hollow, Utah. —Continued

\begin{tabular}{|c|c|c|c|c|c|c|c|c|c|c|c|c|c|}
\hline $\begin{array}{c}\text { Site } \\
\text { num- } \\
\text { ber }\end{array}$ & $\begin{array}{c}\text { Site } \\
\text { name }\end{array}$ & Date sampled & $\begin{array}{c}\text { Water } \\
\text { temp- } \\
\text { erature } \\
\left({ }^{\circ} \mathrm{C}\right)\end{array}$ & $\begin{array}{c}\text { Specific } \\
\text { conduct- } \\
\text { ance } \\
(\mu \mathrm{S} / \mathrm{cm})\end{array}$ & $\begin{array}{c}\text { pH } \\
\text { (standard } \\
\text { units) }\end{array}$ & $\begin{array}{c}\text { Dissolved } \\
\text { oxygen } \\
\text { (mg/L and } \\
\text { percent } \\
\text { saturation) }\end{array}$ & $\begin{array}{c}\text { Total } \\
\text { dissolved- } \\
\text { gas } \\
\text { pressure } \\
(\mathrm{mm} \mathrm{Hg})\end{array}$ & $\begin{array}{c}\text { Chloride } \\
\text { (mg/L } \\
\text { as Cl) }\end{array}$ & $\begin{array}{c}\text { Bromide } \\
\text { (mg/L } \\
\text { as } \mathrm{Br} \text { ) }\end{array}$ & $\begin{array}{c}\text { Chloride/ } \\
\text { bromide } \\
\text { ratio }\end{array}$ & $\begin{array}{c}\text { Arsenic } \\
(\mu \mathrm{g} / \mathrm{L} \\
\text { as As) }\end{array}$ & $\begin{array}{c}\text { Deuterium } \\
\left(\delta^{2} \mathrm{H} \text { in }\right. \\
\text { per mil })\end{array}$ & $\begin{array}{c}\text { Oxygen-18 } \\
\left(\delta^{18} 0 \text { in }\right. \\
\text { per mil })\end{array}$ \\
\hline & & $1 / 18 / 2006$ & - & 460 & 7.9 & - & - & 27.7 & 0.18 & 150 & 10.3 & - & - \\
\hline & & $2 / 15 / 2007$ & - & 450 & 7.8 & $\begin{array}{c}7.9 \\
(90 \%)\end{array}$ & - & 27.6 & .17 & 160 & 11.1 & -84.4 & -10.56 \\
\hline \multirow[t]{9}{*}{36} & WD 11 & $6 / 14 / 2001$ & 18.5 & 420 & 7.8 & $\begin{array}{c}8.1 \\
(91 \%)\end{array}$ & 860 & 14.0 & .10 & 140 & - & -85.1 & -9.70 \\
\hline & & $9 / 14 / 2001$ & 18.5 & 450 & 7.7 & $\begin{array}{c}8.6 \\
(103 \%)\end{array}$ & 900 & 22.5 & .15 & 150 & - & -86.2 & -10.79 \\
\hline & & 12/16/2002 & 18.2 & 455 & 7.6 & $\begin{array}{c}8.1 \\
(100 \%)\end{array}$ & 890 & - & - & - & 7.3 & - & - \\
\hline & & $10 / 7 / 2003$ & 18.5 & 800 & 7.8 & $\begin{array}{c}19.4 \\
(220 \%)\end{array}$ & ${ }^{1} 1,700$ & 64.3 & .25 & 190 & 15.3 & - & - \\
\hline & & 5/3/2004 & 18.4 & 680 & 7.7 & $\begin{array}{c}21.5 \\
(260 \%)\end{array}$ & ${ }^{1} 1,900$ & 49.8 & .25 & 200 & 15.3 & - & - \\
\hline & & 2/9/2005 & 18.0 & 960 & 8.1 & $\begin{array}{c}22.1 \\
(258 \%)\end{array}$ & ${ }^{1} 2,200$ & 65.3 & .21 & 310 & 17.0 & - & - \\
\hline & & 4/5/2005 & 17.8 & 930 & 7.9 & $\begin{array}{c}25.2 \\
(293 \%)\end{array}$ & ${ }^{1}>2,300$ & - & - & - & - & - & - \\
\hline & & $1 / 18 / 2006$ & 17.6 & 980 & 7.9 & $\begin{array}{c}23.0 \\
(270 \%)\end{array}$ & ${ }^{1}>2,300$ & 64.0 & .13 & 500 & 10.7 & - & - \\
\hline & & $2 / 14 / 2007$ & 17.1 & 820 & 7.6 & $\begin{array}{c}19.0 \\
(220 \%)\end{array}$ & ${ }^{1}>2,300$ & 55.9 & .07 & 800 & 8.7 & -86.4 & -11.13 \\
\hline \multirow[t]{11}{*}{37} & WD 9 & $5 / 23 / 2001$ & 19.5 & 295 & 7.7 & $\begin{array}{c}8.0 \\
(95 \%)\end{array}$ & 800 & 22.0 & .06 & 370 & 9.4 & -87.9 & -11.47 \\
\hline & & $9 / 14 / 2001$ & 19.4 & 280 & 7.4 & $\begin{array}{c}3.2 \\
(39 \%)\end{array}$ & 790 & 17.9 & .12 & 150 & - & -86.2 & -11.36 \\
\hline & & $9 / 11 / 2002$ & 19.5 & 345 & 7.9 & $\begin{array}{c}1.1 \\
(15 \%)\end{array}$ & 980 & 21.4 & .06 & 360 & 12.0 & -89.0 & -11.50 \\
\hline & & 8/5/2003 & 19.7 & 720 & 7.5 & $\begin{array}{c}19.3 \\
(220 \%)\end{array}$ & ${ }^{1} 1,800$ & - & - & - & 9.8 & - & - \\
\hline & & $10 / 7 / 2003$ & 19.6 & 740 & 7.5 & $\begin{array}{c}17.9 \\
(208 \%)\end{array}$ & 11,600 & 52.7 & .06 & 860 & 8.8 & - & - \\
\hline & & $1 / 6 / 2004$ & 19.4 & 630 & 7.7 & $\begin{array}{c}16.7 \\
(210 \%)\end{array}$ & ${ }^{1} 1,700$ & 56.2 & .08 & 700 & 8.6 & - & - \\
\hline & & $10 / 28 / 2004$ & 18.5 & 760 & 7.6 & $\begin{array}{c}20.7 \\
(247 \%)\end{array}$ & 12,200 & - & - & - & - & - & - \\
\hline & & 2/9/2005 & 18.4 & 780 & 7.7 & $\begin{array}{c}20.2 \\
(242 \%)\end{array}$ & ${ }^{1}>2,300$ & 56.0 & .10 & 560 & 6.8 & - & - \\
\hline & & 4/5/2005 & 18.5 & 820 & 7.4 & $\begin{array}{c}23.2 \\
(273 \%)\end{array}$ & ${ }^{1}>2,300$ & - & - & - & - & - & - \\
\hline & & $1 / 18 / 2006$ & 18.0 & 1,230 & 7.9 & $\begin{array}{c}15.0 \\
(180 \%)\end{array}$ & ${ }^{1} 1,900$ & 42.4 & .07 & 600 & 5.4 & - & - \\
\hline & & $2 / 14 / 2007$ & 17.3 & 790 & 7.4 & $\begin{array}{c}4.6 \\
(53 \%)\end{array}$ & ${ }^{1} 1,600$ & 45.4 & .06 & 760 & 6.2 & -84.0 & -10.75 \\
\hline \multirow[t]{6}{*}{-} & $\begin{array}{l}{ }^{2} \text { Reser- } \\
\text { voir }\end{array}$ & 9/10/2002 & 24.2 & 1,000 & 8.8 & $\begin{array}{c}2.3 \\
(30 \%)\end{array}$ & - & 76.0 & .02 & 3,800 & 2.0 & -67.0 & -6.20 \\
\hline & & 12/18/2002 & 7.9 & 860 & 8.4 & $\begin{array}{c}10.2 \\
(99 \%)\end{array}$ & 670 & - & - & - & - & - & - \\
\hline & & 3/20/2003 & 11.1 & 830 & 8.2 & $\begin{array}{c}8.4 \\
(100 \%)\end{array}$ & 680 & - & - & - & 0.9 & -94.0 & -12.68 \\
\hline & & $5 / 6 / 2003$ & 17.6 & 820 & - & $\begin{array}{c}3.1 \\
(38 \%)\end{array}$ & 680 & - & - & - & - & - & - \\
\hline & & $6 / 10 / 2003$ & 23.6 & 850 & 8.2 & $\begin{array}{c}8.8 \\
(115 \%)\end{array}$ & 680 & - & - & - & - & - & - \\
\hline & & $8 / 6 / 2003$ & 26.0 & 930 & 7.6 & $\begin{array}{c}3.6 \\
(50 \%)\end{array}$ & 690 & - & - & - & 2.0 & - & - \\
\hline
\end{tabular}


Table 1. Selected physical properties and concentration of chemical constituents in ground-and surface-water samples collected from selected sites in Sand Hollow, Utah.-Continued

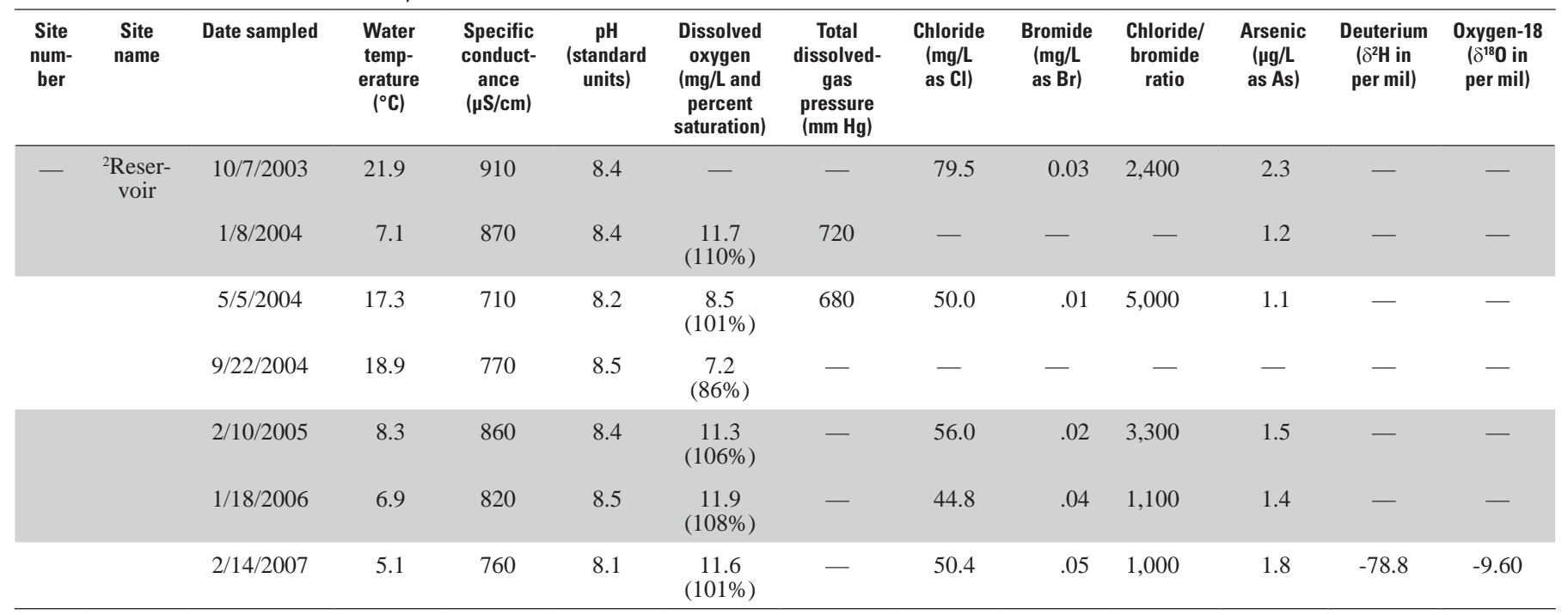

\footnotetext{
${ }^{1}$ Total dissolved-gas pressure may not be accurate; beyond the linear range of the 30-psi pressure transducer.
}

${ }^{2}$ Sample collected from Sand Hollow Reservoir at boat ramp.

was dry prior to the inception of the reservoir. Arsenic concentrations as high as $90 \mu \mathrm{g} / \mathrm{L}$ were measured shortly after inception of the reservoir in October 2002, decreased rapidly to $36 \mu \mathrm{g} / \mathrm{L}$ in October 2003, and since have fluctuated between 42 and $46 \mu \mathrm{g} / \mathrm{L}$ (Heilweil and others, 2005; Heilweil and Susong, 2007). An arsenic concentration of $41.9 \mu \mathrm{g} / \mathrm{L}$ during February 2007 shows continued persistence of arsenic, possibly caused by continued desorption from the surface of iron hydroxides ("Moki marbles") present in the sandstone.

Since 2002, elevated total dissolved-gas (TDG) pressures and dissolved-oxygen concentrations have been measured at wells closest to the reservoir, which is consistent with rising water levels and air entrapment in the sediments and underlying sandstone during the initial filling of the reservoir. Similar air entrapment was documented during an infiltration pond experiment conducted just north of Sand Hollow Reservoir (Heilweil and others, 2004). Between 2001 and 2007, TDG pressures at the closest 2-in. monitoring wells (sites 9, 36, and 37) increased from about 800 millimeters of mercury (mm Hg) to between 1,600 and 2,300 mm Hg (about three times atmospherically equilibrated concentrations; fig. 4), confirming the presence of trapped gas in the soils and sandstone beneath the reservoir. It should be noted that the multi-parameter sonde used for TDG pressure measurements relies on a 30-psi pressure transducer; TDG pressures beyond about 1,500 mm Hg exceed its calibration range. Measured values between 1,500 and 2,300 $\mathrm{mm} \mathrm{Hg}$, therefore, have an error that has not yet been quantified, whereas measurements less than 1,500 have an error of less than 5 percent. Dissolved-oxygen concentrations greatly increased at these same three monitoring wells from a background of about $8 \mathrm{mg} / \mathrm{L}$ to as much as $23 \mathrm{mg} / \mathrm{L}$ (table 1). At site 37 (55 ft from the reservoir), both TDG pres- sure and dissolved oxygen peaked at more than 2,300 $\mathrm{mm} \mathrm{Hg}$ and $23 \mathrm{mg} / \mathrm{L}$, respectively, in 2005 and declined to 1,600 mm $\mathrm{Hg}$ and $4.6 \mathrm{mg} / \mathrm{L}$, respectively, in 2007 (fig. 4). This indicates that trapped air along the flow path between the reservoir and site 37 has begun to dissipate. At site 36 (160 ft from the reservoir), both TDG pressure and dissolved oxygen exceeded similar values of more than 2,300 $\mathrm{mm} \mathrm{Hg}$ and $23 \mathrm{mg} / \mathrm{L}$, respectively, in 2005 and 2006. At site 9 (1,000 ft from the reservoir), TDG pressure and dissolved oxygen reached 1,700 $\mathrm{mm} \mathrm{Hg}$ and $17.7 \mathrm{mg} / \mathrm{L}$, respectively, in 2006.

Specific conductance in ground water is being evaluated as a tracer of artificial recharge. The change in specific conductance of water at the reservoir and in seven monitoring wells is shown in figure 5 . The specific conductance of ground water at sites 37 and 36, located 60 and $160 \mathrm{ft}$ from the reservoir, respectively, was similar in 2007 to the reservoir water $(760 \mu \mathrm{S} / \mathrm{cm})$ and decreased from previously higher values. The peak specific conductance of ground water from these two wells was much higher than the reservoir water and likely represents the mobilization of natural salts that accumulated in the vadose zone prior to the inception of the reservoir. It is not clear if these higher values, however, indicate a mixing with managed aquifer recharge at the front of the plume or the in-situ mobilization of natural vadosezone salts near the monitoring wells with rising ground-water levels. A specific-conductance peak of over 1,200 $\mu \mathrm{S} / \mathrm{cm}$ at site 37 occurred in the winter of 2006, with a subsequent decrease to about $800 \mu \mathrm{S} / \mathrm{cm}$ (similar to reservoir values) by the winter/spring of 2007. The highest specific-conductance measurement at site 36 was about $1,000 \mu \mathrm{S} / \mathrm{cm}$ and also occurred in 2006. Subsequently, specific-conductance values decreased to about $800 \mu \mathrm{S} / \mathrm{cm}$ by the winter of 2007 . The 


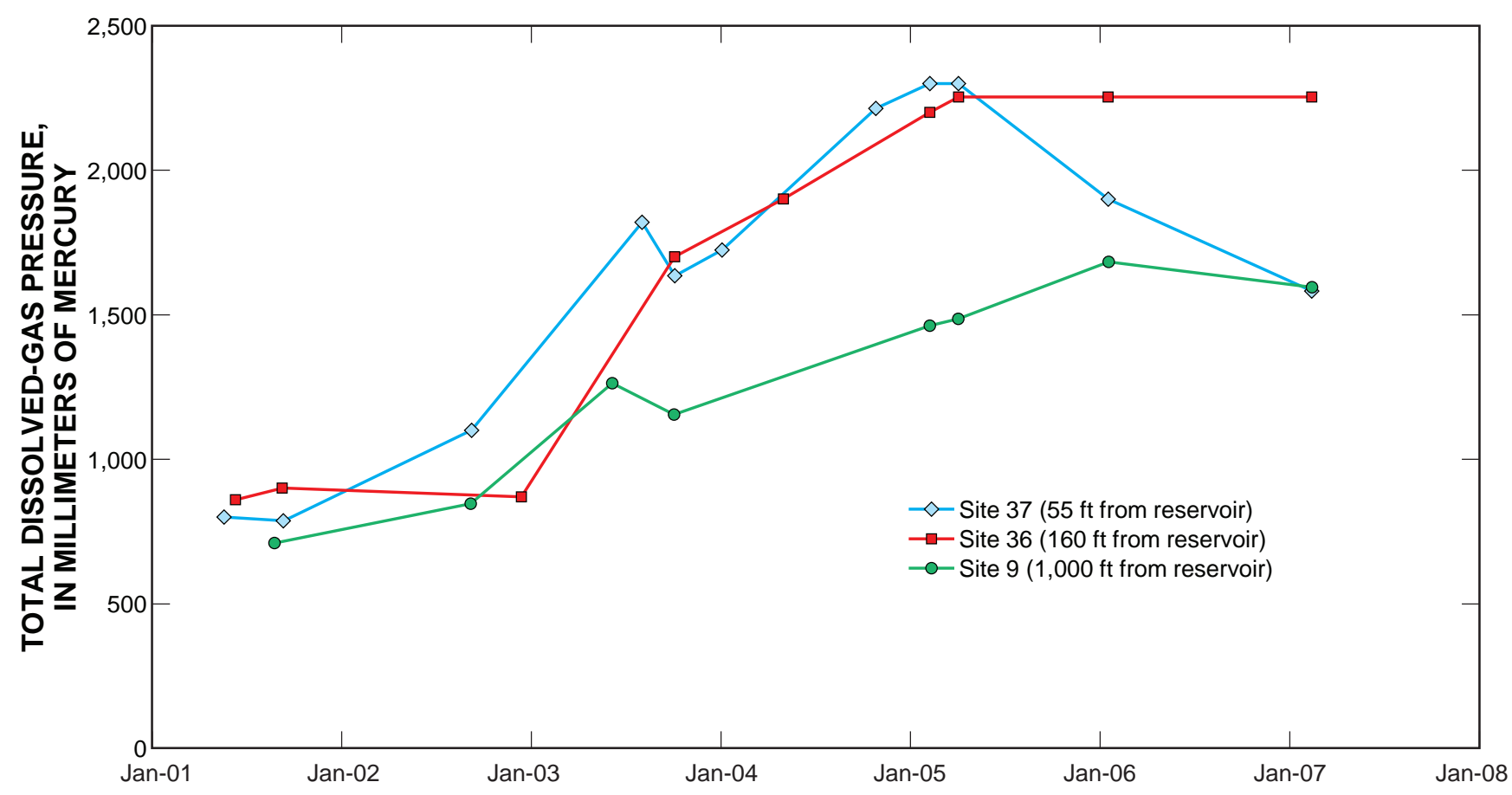

Figure 4. Total dissolved-gas pressure in ground water from selected monitoring wells in Sand Hollow, Utah.

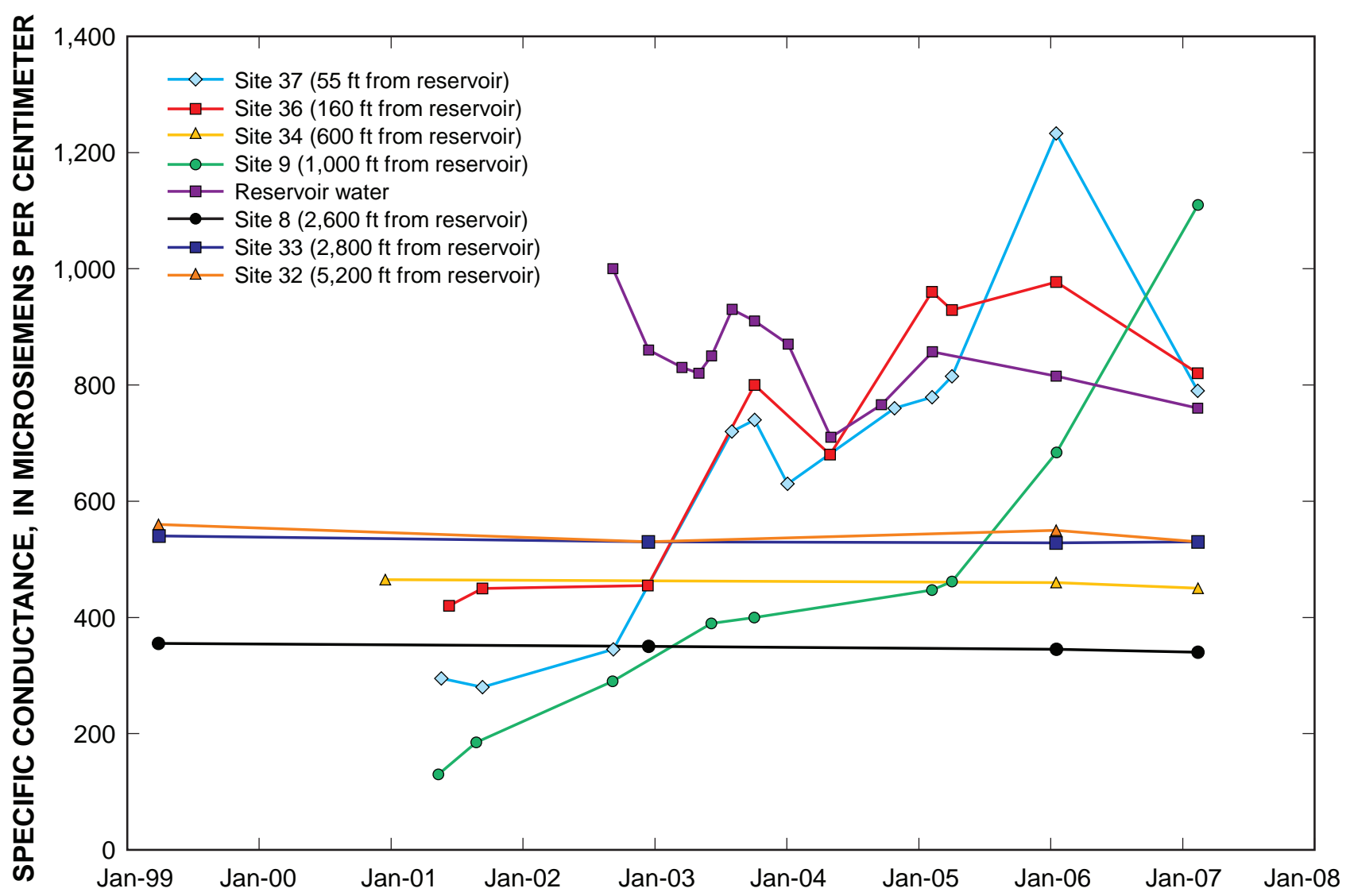

Figure 5. Specific conductance of reservoir water and ground water from selected monitoring wells in Sand Hollow, Utah. 
specific conductance of ground water at site 9 , located $1,000 \mathrm{ft}$ north of the reservoir, has risen steadily from $130 \mu \mathrm{S} / \mathrm{cm}$ prior to the inception of the reservoir in 2002 to $1,110 \mu \mathrm{S} / \mathrm{cm}$ in 2007, but the arrival of a peak is not yet evident. Interestingly, specific-conductance values at site 34, located $600 \mathrm{ft}$ west of the reservoir have not changed substantially since the inception of the reservoir. The other monitoring wells farther from the reservoir (sites 8, 32, and 33) also have not shown an increase in specific conductance through 2007.

Chloride $(\mathrm{Cl})$ concentrations in Sand Hollow Reservoir have ranged from about 45 to $80 \mathrm{mg} / \mathrm{L}$ since 2002. These values generally are higher than $\mathrm{Cl}$ concentrations in natural ground water in Sand Hollow prior to the reservoir, which ranged from 7 to $45 \mathrm{mg} / \mathrm{L}$. Like specific conductance, however, $\mathrm{Cl}$ concentrations may be problematic for interpreting the peak arrival of artificial recharge. This is because vadose zone pore water from boreholes drilled prior to the reservoir showed very high concentrations of up to 14,700 mg/L (Heilweil and others, 2006), much higher than natural ground water and reservoir water. Ground-water $\mathrm{Cl}$ concentrations during the 2007 sampling ranged from 16.8 $\mathrm{mg} / \mathrm{L}$ at site 8 to $173 \mathrm{mg} / \mathrm{L}$ at site 9 (table 1 ), exceeding reservoir concentrations at site 36 and site 37, which are nearest the reservoir. Similar to specific conductance, it is hypothesized that high $\mathrm{Cl}$ concentrations are caused by the mobilization of vadose-zone salts. It currently is not understood if this high $\mathrm{Cl}$ concentration indicates mixing with natural salts from beneath the reservoir (marking the first arrival of artificial recharge) or represents the mobilization of in-situ vadose-zone salts near the individual monitoring wells with rising ground-water levels. Also, natural ground-water $\mathrm{Cl}$ concentrations of about $45 \mathrm{mg} / \mathrm{L}$ at sites 33 and 32 located farthest from the reservoir (2,800 ft and 5,200 ft, respectively) indicate that $\mathrm{Cl}$ may not be a useful tracer as managed aquifer recharge moves farther from the reservoir.

Chloride/bromide ratios $(\mathrm{Cl} / \mathrm{Br})$ of water in the reservoir may be more useful for tracing the movement of artificial recharge from the reservoir through the aquifer than the use of chloride alone. Natural, pre-reservoir $\mathrm{Cl} / \mathrm{Br}$ ratios in Sand Hollow ground water ranged from 140 to 370 . Similarly, Cl/ $\mathrm{Br}$ ratios in vadose-zone pore water from boreholes drilled prior to the reservoir ranged from 125 to 250 (Heilweil and others, 2006). In contrast, $\mathrm{Cl} / \mathrm{Br}$ ratios in Sand Hollow Reservoir water have been as high as 5,000, but ratios during 2006 and 2007 have declined to around 1,000. The $\mathrm{Cl} / \mathrm{Br}$ ratio of managed aquifer recharge that first enters the underlying Navajo Sandstone, however, may be closer to 700 . This is based on the $\mathrm{Cl} / \mathrm{Br}$ ratios in water from site 28 (table 1 , fig. 6). The piezometer at site 28, located at the base of the North Dam, was a dry well before the inception of Sand Hollow Reservoir. Recent (2006-07) Cl/Br ratios from this site (680 and 740, respectively) are considered representative of the geochemistry of artificial recharge entering the uppermost part of the aquifer. This indicates that there may be a biological or salt-dissolution process that preferentially increases $\mathrm{Cl}$ or decreases $\mathrm{Br}$ as managed aquifer recharge moves through the sediments beneath the reservoir. Ground-water $\mathrm{Cl} / \mathrm{Br}$ ratios in February 2007 at the Sand Hollow monitoring wells ranged

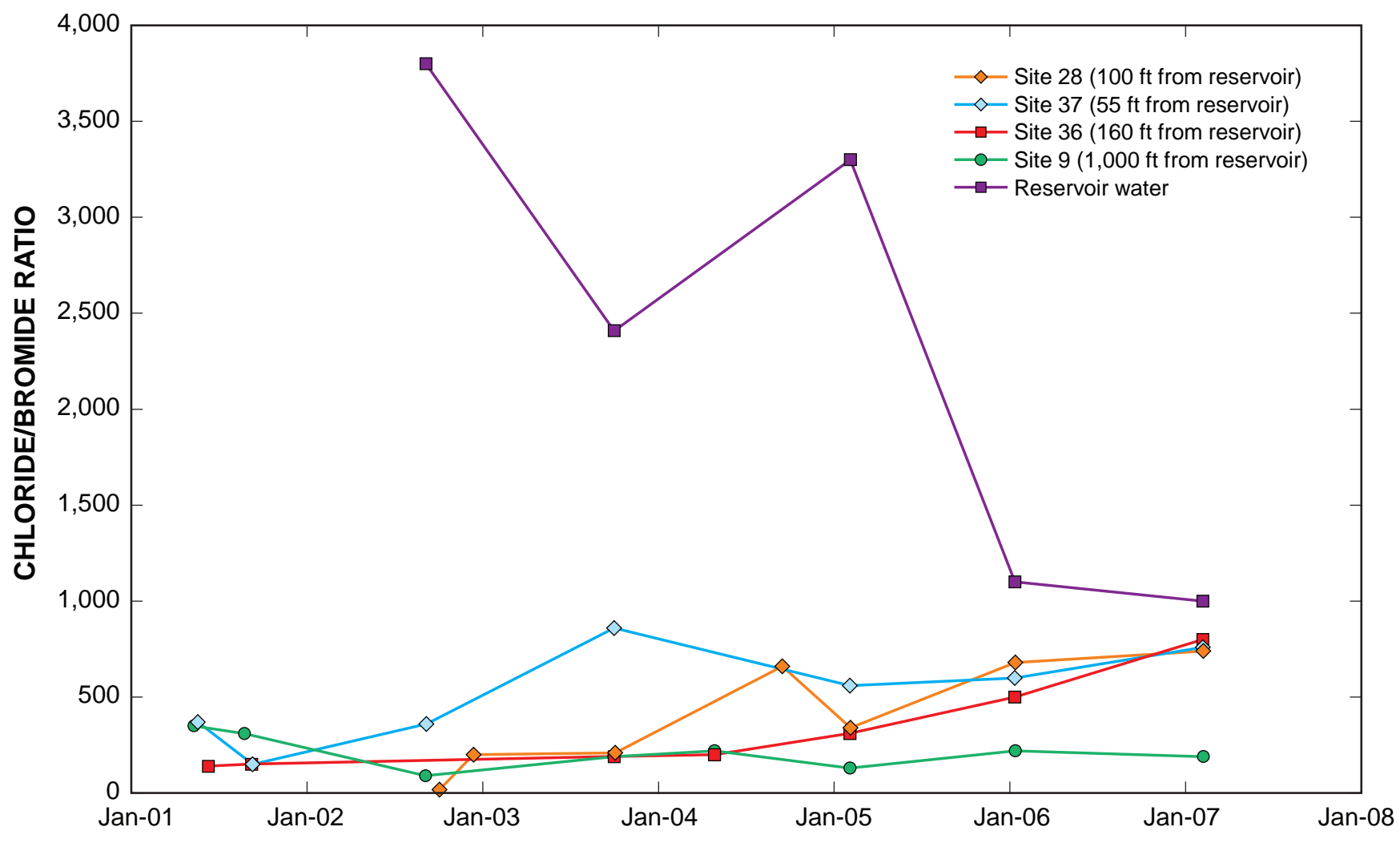

Figure 6. Chloride/bromide ratios of reservoir water and ground water from selected monitoring wells in Sand Hollow, Utah. 
from 160 to 800 . The highest 2007 ground-water $\mathrm{Cl} / \mathrm{Br}$ ratios of about 800 (representing managed aquifer recharge) were from sites 36 and 37, located closest to the reservoir. The $\mathrm{Cl} / \mathrm{Br}$ ratios in water from these two wells generally have increased from pre-reservoir ratios of 140 and 370, respectively (fig. 6). $\mathrm{Cl} / \mathrm{Br}$ ratios at sites $8,9,32,33$, and 34, located between 600 and 5,200 ft from the reservoir, were between 160 and 190, consistent with previously reported pre-reservoir background ratios (Heilweil and others, 2005).

In summary, selected tracers of managed aquifer recharge in monitoring wells near Sand Hollow Reservoir have not shown consistent peak breakthrough dates. Site 37 (60 ft from the reservoir) illustrates this complexity, with peak $\mathrm{Cl} / \mathrm{Br}$ ratios occurring in 2003, peak $\mathrm{Cl}$ occurring in 2004, peak dissolved oxygen and TDG pressure occurring in 2005, and peak specific-conductance values occurring in 2006. Interpreting these differing peaks for estimating the arrival of managed aquifer recharge and determining ground-water travel times from the reservoir is problematic. Because of the difficulty in discerning this peak arrival of managed aquifer recharge from the reservoir at nearby monitoring wells, additional tracers currently are being evaluated, including stable isotopes $\left(\delta^{2} \mathrm{H}\right.$, $\left.\delta^{18} \mathrm{O}\right)$ and tritium $\left({ }^{3} \mathrm{H}\right)$. These constituents were measured in wells prior to the construction of Sand Hollow Reservoir to establish baseline conditions. It is hypothesized that the stable isotopes of managed aquifer recharge water either may be (1) more depleted than native ground water at Sand Hollow because of its high-elevation precipitation source in and around Zion National Park or (2) show an oxygen-isotopic shift caused by evaporative enrichment in the reservoir. Preliminary results (table 1 ) indicate that the isotopic signature of Sand Hollow Reservoir water can be highly variable, with $\delta^{18} \mathrm{O}$ ranging from -6.2 to -12.7 per mil and $\delta^{2} \mathrm{H}$ ranging from -67 to -94 per mil. These values suggest varying degrees of both isotopic depletion and evaporative enrichment. Further study is needed before final conclusions can be drawn regarding the utility of stable isotopes for tracing managed aquifer recharge.

\section{Meteorology and Precipitation Data}

Meteorology data have been collected continuously at a weather station (fig. 2) in Sand Hollow since January 1998 and have been used for evaluating evaporation and precipitation. Parameters measured include air temperature, wind speed, wind direction, precipitation, relative humidity, and solar radiation. Instrumentation includes a Vaisala temperature and RH probe, a RM Young wind monitor, a Weathertronics tipping bucket rain gage, and a Matrix MK 1-G Sol-A-Meter with a spectral response from 0.35 to 1.15 microns. Sensors collect data every minute, with average hourly and daily values (except for cumulative precipitation, computed and stored on a data logger). From January 13, 1998, to December 30,2007 , daily average air temperature ranged from -6 to $37^{\circ} \mathrm{C}$ and daily average solar radiation ranged from 5.3 to 130 calories/in ${ }^{2}$ per day.
Monthly precipitation from January 1998 through December 2007 ranged from 0 to almost 4 in. (fig. 7). Above normal precipitation during 2004 and 2005 allowed the WCWCD to divert large quantities of surface water from the Virgin River, nearly filling Sand Hollow Reservoir to capacity in February 2006. Precipitation and runoff subsided during 2006 and 2007; therefore, inflow to the reservoir decreased during these 2 years.

\section{Reservoir Water Temperature Data}

Continuous water-temperature measurements were made in Sand Hollow Reservoir and used for evaluating effects of water viscosity changes on seepage rates beneath the reservoir. A string of five thermistors was installed in the deepest part of Sand Hollow Reservoir, about $300 \mathrm{ft}$ from the North Dam. The thermistors initially were attached to a floating buoy at depths of $0.3,3.3,9.9,16.5$, and $33 \mathrm{ft}$ or at the bottom of the reservoir, if shallower. The thermistors are reported to have an accuracy of better than $0.5^{\circ} \mathrm{C}$ over the temperature range of 0 to $35^{\circ} \mathrm{C}$. Both the previous (January 2003 through May 2006) and more recent (February 2007 through December 2007) temperature data are shown in figure 8. Water temperature from January 2003 through December 2007 has ranged from about 3 to $30^{\circ} \mathrm{C}$. There are gaps in the temperature data due to equipment loss: (1) April 26, 2007, through December 31, 2007, at the 0.3-ft depth; (2) May 9, 2006, through February 7, 2007, at the 9.9-ft depth; and (3) February 16, 2007, through December 31, 2007, at the 33-ft depth.

\section{Calculation of Recharge from Sand Hollow Reservoir}

Ground-water recharge to the Navajo aquifer underlying Sand Hollow Reservoir is calculated with the following waterbudget equation (modified from Heilweil and others, 2005):

$$
R=I_{s w}+P-O_{s w} \pm \Delta S-E
$$

where:

$R$ is recharge,

$I_{s w}$ is surface-water inflow,

$P \quad$ is the amount of precipitation falling directly on the reservoir,

$O_{s w}$ is surface-water outflow,

$\Delta S$ is change in surface-water storage, and

$E$ is evaporation.

The two previous reports documenting monthly groundwater recharge beneath Sand Hollow Reservoir through August 2006 (Heilweil and others, 2005; Heilweil and Susong, 2007) did not include precipitation falling directly on the reservoir. With the availability of daily reservoir stage data beginning in January 2005, the water budgets were calculated daily using equation 1 and then compiled into monthly totals. 


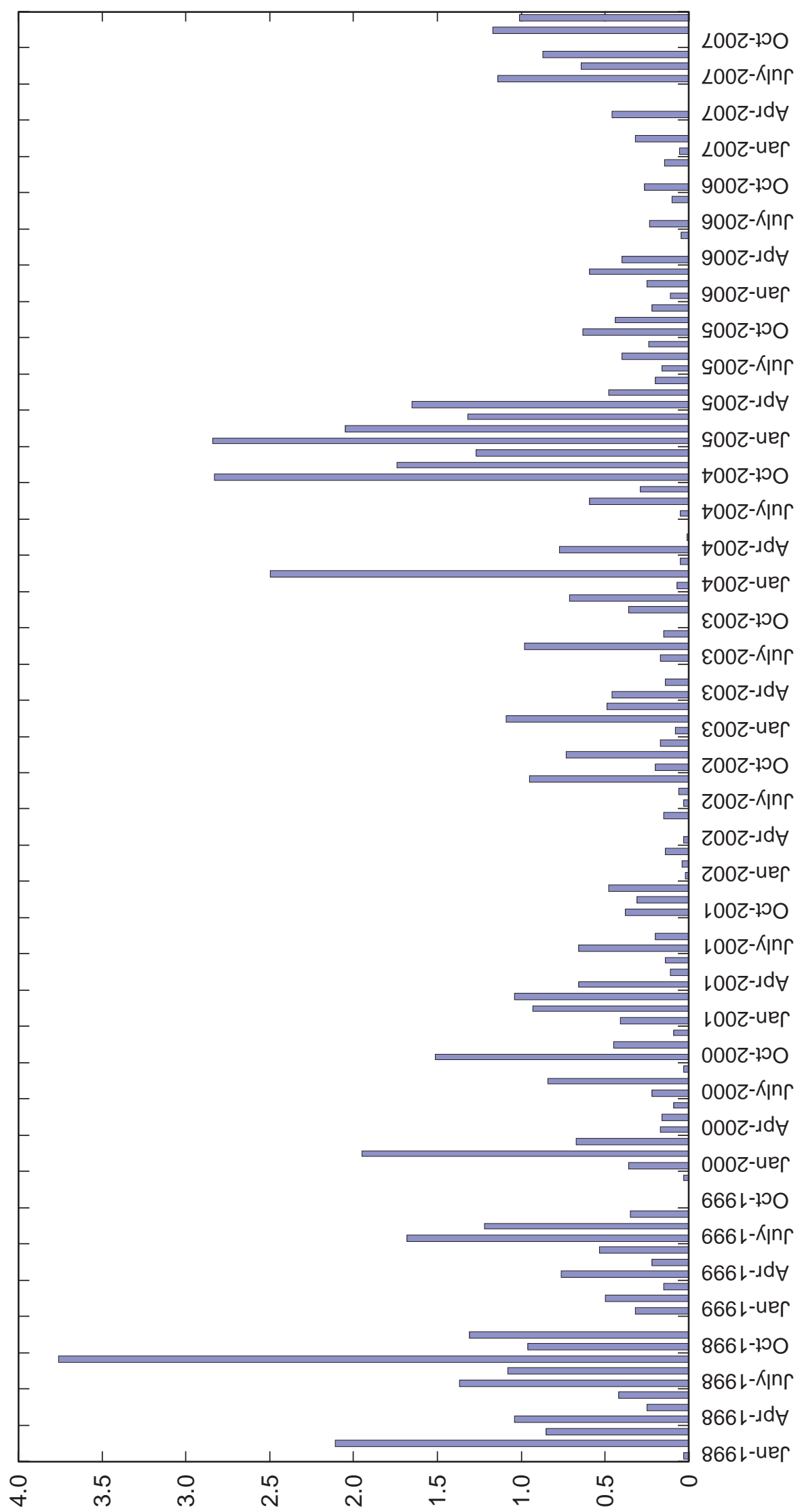

S $\exists H O N I$ NI ‘NOIL $\forall$ لالdIJ $\exists y d$ 


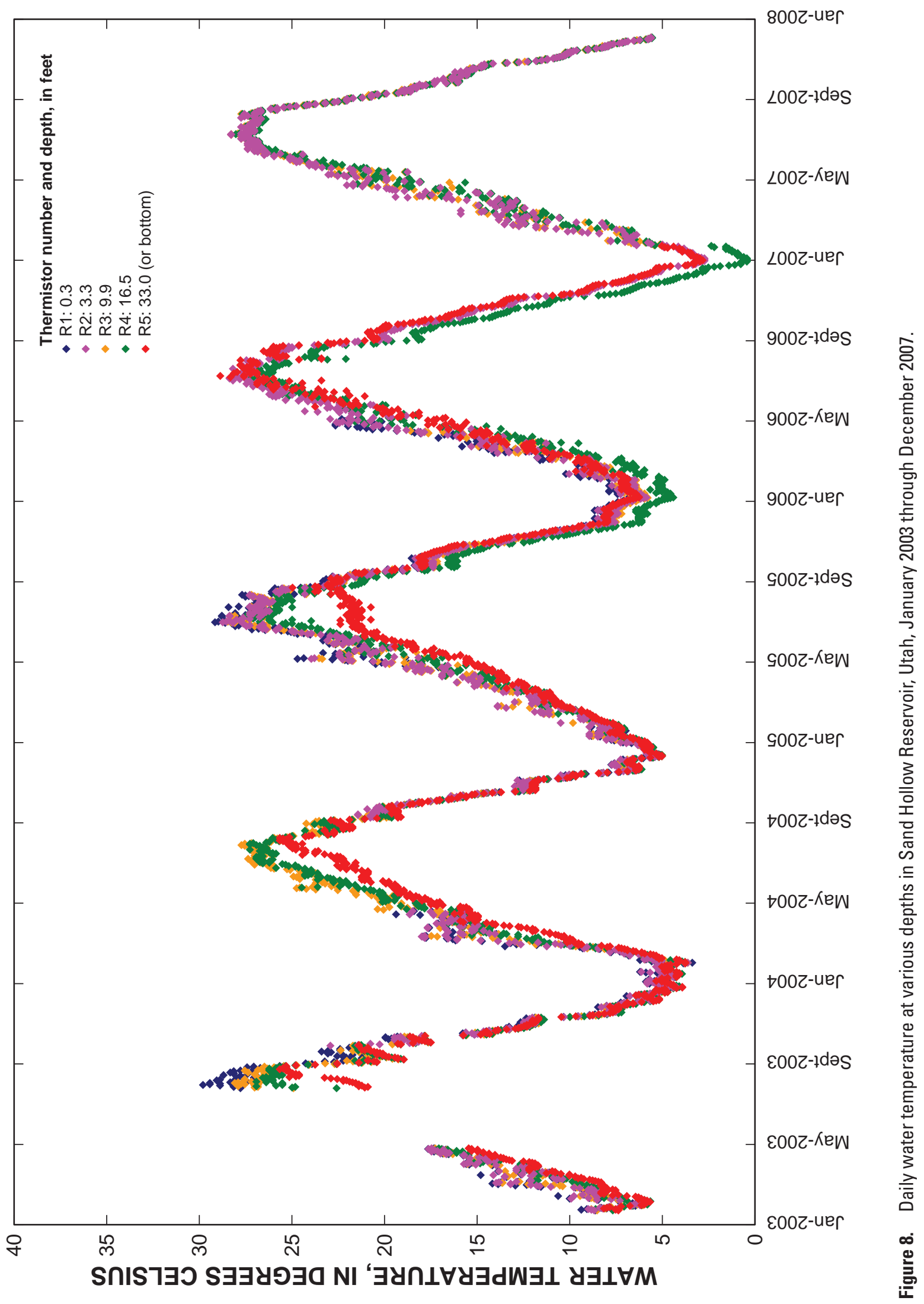


An additional term, $\mathrm{P}$, for precipitation falling directly on the reservoir was added to this water-balance equation to account for increased reservoir volume caused by rainfall. Equation (1), however, does not account for precipitation runoff to the reservoir. Because of high evaporation rates and permeable surficial soils, precipitation events seldom produce runoff that reaches the lower part of Sand Hollow (L. Jessop, Washington County Water Conservancy District, oral commun., 2001).

Monthly water-budget values for Sand Hollow Reservoir are shown in table 2. Values from March 2002 through January 2005 are monthly averages, except for reservoir altitude and storage (specified at the end of each month). Beginning in February 2005, budget estimates include precipitation falling on the reservoir surface. One error in Heilweil and Susong (2007) has been corrected (table 2); the "monthly surfacewater inflow or outflow" for the months of September and October 2004 incorrectly were reported as 3,600 and 3,630 acre-ft, rather than 600 and 630 acre-ft, respectively.

Beginning in February 2005, the values for "monthly evaporation rate," "monthly evaporation," and "monthly recharge" are the sum of daily values and the "reservoir surface area" is the average of all daily values for each month, compared to monthly averages prior to February 2005. Also, beginning in February 2005, the "monthly surface-water inflow or outflow” column of table 2 includes precipitation falling directly on the reservoir surface, calculated by multiplying the daily precipitation recorded by the Sand Hollow weather station by the daily reservoir surface area, based on stage/area relations for the reservoir (RBG Engineering, written commun., 2002; Washington County Water Conservancy District, written commun., 2006). Precipitation falling directly on the reservoir was not included in the water-budget calculations prior to February 2005. Evaporation and recharge values previously reported in Heilweil and Susong (2007) for February 2005 through August 2006 have been revised slightly and the monthly water-budget numbers presented in this report are considered to be more accurate.

\section{Surface-Water Inflow and Outflow to Sand Hollow Reservoir}

Average daily surface-water inflow and outflow to Sand Hollow Reservoir was reported by the WCWCD. Five turbines with Sparling Tigerman in-line totalizing flow meters are linked to a computer system that combines and records total daily discharge, in gallons. The in-line flow meters have electronic modules on which calibration diagnostics are done monthly by the WCWCD. Each module is removed annually and factory recalibrated.

"Monthly net surface-water inflow/outflow" from March 2002 through December 2007 (table 2) ranged from -3,120 acre-ft (negative value represents net outflow from Sand Hollow) to 6,620 acre-ft (positive value represents net inflow to Sand Hollow). Because of problems with monitoring equipment, inflows from September 2004 through February 2005 are estimated, based on previous inflow history and changes in reservoir altitudes.

\section{Changes in Sand Hollow Reservoir Storage}

Changes in surface-water storage were calculated from daily reservoir altitude measurements and altitude-volume relations for Sand Hollow Reservoir (Brad Price, RBG Engineering, written commun., 2002; Washington County Water Conservancy District, written commun., 2006). Reservoir storage between September 2006 and December 2007 ranged from about 32,000 to 48,000 acre-ft (table 2).

\section{Sand Hollow Reservoir Evaporation}

The McGuinness and Bordne (1971) version of the Jensen-Haise Method was selected for calculating evaporation from Sand Hollow Reservoir and was used during this study. The method is based on the relation:

$$
P E T=\left\{\left[\left(\left(0.01\left(1.8 T_{a}+32\right)-0.37\right)\left(0.155 Q_{s}\right)\right] 0.000673\right\}\right.
$$

where

$P E T$ is potential evaporation, in inches per day,

$T_{a} \quad$ is air temperature, in degrees Celsius, and

$Q_{s} \quad$ is solar radiation, in calories per square inch per day.

By using air temperature and solar radiation from the nearby weather station (fig. 2), daily evaporation rates were calculated with equation 2 . These daily evaporation rates were added to determine total monthly evaporation rates, which ranged from 0.04 to $0.97 \mathrm{ft}$ from March 2002 through December 2007 (table 2; Heilweil and others, 2005; Heilweil and Susong, 2007). On the basis of reservoir altitude-area relations (Brad Price, RBG Engineering, written commun., 2002), the monthly average reservoir surface area increased gradually to about 1,300 acres in 2006 and then decreased to about 1,000 acres in December 2007. Multiplying evaporation rates by average reservoir surface area yielded monthly evaporation losses ranging from about 20 to 1,200 acre-ft between March 2002 and December 2007.

\section{Estimated Managed Aquifer Recharge}

To estimate ground-water recharge beneath Sand Hollow Reservoir, evaporation (E), total monthly inflows $\left(\mathrm{I}_{\mathrm{sw}}\right)$, outflows $\left(\mathrm{O}_{\mathrm{sw}}\right)$, and changes in surface-water storage $(\Delta \mathrm{S})$ were used in equation (1) to calculate monthly estimates of ground-water recharge. Monthly recharge from September 2006 through December 2007 ranged from about 440 to 2,800 acre-ft (table 2, fig. 9), totaling about 16,200 acre-ft. Since the inception of the reservoir (March 2002 through December 
Table 2. Reservoir data and estimated evaporation and ground-water recharge at Sand Hollow, Utah, 2002-07.

[Reservoir altitude and storage values are from the last day of each month; Reservoir surface area is an average of the daily values for each month]

\begin{tabular}{|c|c|c|c|c|c|c|c|c|c|}
\hline Month & $\begin{array}{l}\text { Reservoir } \\
\text { altitude } \\
\text { (feet) }\end{array}$ & $\begin{array}{l}\text { Reservoir } \\
\text { storage } \\
\text { (acre-feet) }\end{array}$ & $\begin{array}{c}\text { Monthly net } \\
\text { surface-water } \\
\text { inflow (+)/ } \\
\text { outflow (-) } \\
\text { (acre-feet) }\end{array}$ & $\begin{array}{l}\text { Monthly } \\
\text { reservoir } \\
\text { storage } \\
\text { change } \\
\text { (acre-feet) }\end{array}$ & $\begin{array}{l}\text { Reservoir } \\
\text { surface } \\
\text { area } \\
\text { (acres) }\end{array}$ & $\begin{array}{c}\text { Monthly } \\
\text { evaporation } \\
\text { rate } \\
\text { (feet) }\end{array}$ & $\begin{array}{l}\text { Monthly } \\
\text { evaporation } \\
\text { (acre-feet) }\end{array}$ & $\begin{array}{l}\text { Monthly } \\
\text { ground-water } \\
\text { recharge } \\
\text { (acre-feet) }\end{array}$ & $\begin{array}{l}\text { Ground- } \\
\text { water } \\
\text { recharge } \\
\text { rate } \\
\text { (feet/day) }\end{array}$ \\
\hline M arch-02 & 3,001 & 3,090 & 6,620 & 3,090 & 260 & 0.24 & 60 & 3,470 & 0.43 \\
\hline A pril-02 & 3,003 & 3,500 & 3,690 & 410 & 280 & .46 & 130 & 3,150 & .38 \\
\hline M ay-02 & 3,001 & 3,090 & 2,450 & -410 & 260 & .68 & 170 & 2,690 & .33 \\
\hline July-02 & 2,997 & 2,050 & 0 & -430 & 210 & .90 & 190 & 240 & .04 \\
\hline A ugust-02 & 2,995 & 1,650 & 0 & -400 & 180 & .81 & 150 & 250 & .04 \\
\hline September-02 & 2,994 & 1,300 & 0 & -350 & 140 & .47 & 70 & 280 & .07 \\
\hline October-02 & 2,995 & 1,500 & 790 & 200 & 160 & .26 & 40 & 550 & .11 \\
\hline February-03 & 3,019 & 10,670 & 2,850 & 910 & 570 & .10 & 60 & 1,880 & .12 \\
\hline M arch-03 & 3,020 & 10,930 & 1,930 & 260 & 580 & .24 & 140 & 1,530 & .09 \\
\hline A pril-03 & 3,019 & 10,680 & 540 & -250 & 570 & .37 & 210 & 580 & .03 \\
\hline M ay-03 & 3,018 & 9,930 & 0 & -750 & 540 & .66 & 350 & 400 & .02 \\
\hline J une-03 & 3,010 & 6,040 & $-3,120$ & $-3,890$ & 390 & .89 & 350 & 420 & .04 \\
\hline July-03 & 3,002 & 3,200 & $-2,020$ & $-2,840$ & 240 & .92 & 220 & 600 & .08 \\
\hline A ugust-03 & 2,999 & 2,540 & 0 & -660 & 230 & .75 & 170 & 490 & .07 \\
\hline September-03 & 2,997 & 2,100 & 0 & -440 & 220 & .58 & 130 & 310 & .05 \\
\hline October-03 & 2,996 & 1,850 & 0 & -250 & 170 & .36 & 60 & 190 & .04 \\
\hline M ay-04 & 3,026 & 15,830 & 2,050 & 760 & 780 & .72 & 560 & 730 & .03 \\
\hline J une-04 & 3,025 & 14,400 & 0 & $-1,430$ & 750 & .87 & 650 & 780 & .03 \\
\hline July-04 & 3,023 & 13,000 & 0 & $-1,400$ & 680 & .94 & 640 & 760 & .04 \\
\hline A ugust-04 & 3,021 & 11,670 & 0 & $-1,330$ & 680 & .78 & 520 & 810 & .04 \\
\hline September-04 & 3,019 & 11,260 & ${ }^{1} 600$ & -410 & 630 & .53 & 340 & 670 & .04 \\
\hline October-04 & 3,019 & 11,040 & ${ }^{1} 630$ & -220 & 610 & .25 & 150 & 700 & .04 \\
\hline N ovember- 04 & 3,022 & 12,650 & 12,300 & 1,610 & 630 & .10 & 60 & 610 & .03 \\
\hline December-04 & 3,023 & 13,390 & ${ }^{1} 1,400$ & 740 & 670 & .06 & 40 & 620 & .03 \\
\hline J anuary-05 & 3,027 & 16,201 & 13,500 & 2,810 & 740 & .07 & 50 & 640 & .03 \\
\hline February-05 & 3,032 & 20,283 & 15,200 & 3,900 & 780 & .11 & 90 & 1,030 & .05 \\
\hline M arch-05 & 3,037 & 25,030 & 6,530 & 4,590 & 877 & .24 & 220 & 1,560 & .06 \\
\hline A pril-05 & 3,041 & 29,219 & 6,180 & 4,060 & 960 & .39 & 380 & 1,620 & .06 \\
\hline M ay-05 & 3,044 & 32,372 & 5,140 & 2,980 & 1,020 & .70 & 730 & 1,510 & .05 \\
\hline June-05 & 3,048 & 35,746 & 6,100 & 3,290 & 1,080 & .75 & 820 & 1,390 & .04 \\
\hline July-05 & 3,049 & 37,277 & 3,600 & 1,410 & 1,120 & .97 & 1,060 & 1,180 & .03 \\
\hline
\end{tabular}


Table 2. Reservoir data and estimated evaporation and ground-water recharge at Sand Hollow, Utah, 2002-07._-Continued

\begin{tabular}{|c|c|c|c|c|c|c|c|c|c|}
\hline Month & $\begin{array}{l}\text { Reservoir } \\
\text { altitude } \\
\text { (feet) }\end{array}$ & $\begin{array}{l}\text { Reservoir } \\
\text { storage } \\
\text { (acre-feet) }\end{array}$ & $\begin{array}{c}\text { Monthly net } \\
\text { surface-water } \\
\text { inflow (+)/ } \\
\text { outflow (-) } \\
\text { (acre-feet) }\end{array}$ & $\begin{array}{l}\text { Monthly } \\
\text { reservoir } \\
\text { storage } \\
\text { change } \\
\text { (acre-feet) }\end{array}$ & $\begin{array}{l}\text { Reservoir } \\
\text { surface } \\
\text { area } \\
\text { (acres) }\end{array}$ & $\begin{array}{l}\text { Monthly } \\
\text { evaporation } \\
\text { rate } \\
\text { (feet) }\end{array}$ & $\begin{array}{c}\text { Monthly } \\
\text { evaporation } \\
\text { (acre-feet) }\end{array}$ & $\begin{array}{l}\text { Monthly } \\
\text { ground-water } \\
\text { recharge } \\
\text { (acre-feet) }\end{array}$ & $\begin{array}{l}\text { Ground- } \\
\text { water } \\
\text { recharge } \\
\text { rate } \\
\text { (feet/day) }\end{array}$ \\
\hline A ugust-05 & 3,050 & 38,668 & 3,390 & 1,340 & 1,140 & 0.75 & 860 & 1,220 & 0.03 \\
\hline September-05 & 3,051 & 39,583 & 3,010 & 870 & 1,160 & .54 & 630 & 1,470 & .04 \\
\hline October-05 & 3,051 & 39,753 & 2,960 & 150 & 1,160 & .28 & 310 & 1,940 & .05 \\
\hline December-05 & 3,056 & 46,115 & 3,380 & 1,690 & 1,250 & .05 & 60 & 1,020 & .03 \\
\hline J anuary-06 & 3,059 & 49,589 & 4,660 & 3,300 & 1,290 & .08 & 100 & 1,010 & .03 \\
\hline February-06 & 3,059 & 49,843 & 1,200 & 120 & 1,320 & .12 & 160 & 860 & .02 \\
\hline M arch-06 & 3,058 & 48,704 & 60 & $-1,100$ & 1,310 & .18 & 240 & 860 & .02 \\
\hline July-06 & 3,058 & 47,919 & 30 & $-1,650$ & 1,300 & .88 & 1,150 & 480 & .01 \\
\hline A ugust-06 & 3,056 & 46,224 & 0 & $-1,640$ & 1,280 & .80 & 1,020 & 680 & .02 \\
\hline September-06 & 3,055 & 44,614 & 10 & $-1,560$ & 1,250 & .52 & 620 & 940 & .03 \\
\hline October-06 & 3,054 & 43,388 & 30 & $-1,170$ & 1,230 & .22 & 260 & 1,270 & .03 \\
\hline N ovember-06 & 3,053 & 42,359 & 0 & -990 & 1,220 & .07 & 80 & 1,150 & .03 \\
\hline December-06 & 3,055 & 45,101 & 4,430 & 2,800 & 1,230 & .04 & 60 & 990 & .03 \\
\hline J anuary-07 & 3,058 & 48,231 & 4,190 & 3,010 & 1,270 & .05 & 60 & 840 & .02 \\
\hline February-07 & 3,057 & 47,632 & 30 & -690 & 1,290 & .13 & 170 & 720 & .02 \\
\hline M arch-07 & 3,057 & 47,663 & 1,210 & 80 & 1,290 & .33 & 440 & 640 & .02 \\
\hline October-07 & 3,046 & 34,282 & -580 & $-3,620$ & 1,110 & .34 & 380 & 2,800 & .08 \\
\hline N ovember-07 & 3,045 & 32,476 & 100 & $-1,740$ & 1,070 & .17 & 180 & 1,730 & .05 \\
\hline December-07 & 3,044 & 31,683 & 90 & -760 & 1,040 & .05 & 60 & 930 & .03 \\
\hline Total & - & - & 126,000 & - & - & - & 25,000 & 69,000 & - \\
\hline
\end{tabular}

${ }^{1}$ Because of problems with monitoring equipment, inflows from September 2004 through February 2005 are estimated based on previous inflow history and changes in reservoir altitude. 
2007), monthly recharge volumes have ranged from about 200 to 3,500 acre-ft. During the same period, total net surfacewater inflow into the reservoir was about 126,000 acre-ft, evaporative loss was about 25,000 acre-ft, and estimated recharge to the underlying Navajo aquifer was about 69,000 acre-ft.

Estimated ground-water recharge rates, on the basis of monthly averages, ranged from 0.01 to $0.43 \mathrm{ft} / \mathrm{d}$, between March 2002 and December 2007. Recharge rates for all but the first 3 months in 2002 are shown in figure 10. Recharge rates for these first 3 months were very high ( 0.33 to $0.43 \mathrm{ft} / \mathrm{d}$ ) and were excluded to better show recent trends and seasonal fluctuations. Since 2002, there has been a gradual decline in recharge rates, superimposed with large seasonal fluctuations. Many years have minimum rates during late spring or early summer, followed by rapidly rising rates in autumn. This was particularly evident during 2007, when rates rapidly increased from a minimum of $0.01 \mathrm{ft} / \mathrm{d}$ in June to $0.08 \mathrm{ft} / \mathrm{d}$ in October. The causes for these seasonal fluctuations currently are being investigated.

Annual inflow, estimated evaporation, and estimated ground-water recharge are shown for 2002 through 2007 in figure 11. Annual inflow ranged from about 5,400 to 54,000 acre-ft; annual estimated evaporation ranged from about 1,000 to 7,000 acre-ft/yr; and annual ground-water recharge ranged from about 9,000 to 16,000 acre-ft/yr. The general increase in reservoir volume and area since 2002 has resulted in a steady increase in the volume of evaporation, with the total volume of water lost through evaporation being more than one-half the volume of ground-water recharge during 2006 and 2007. Total estimated managed aquifer recharge during 2007 was about 12,000 acre-ft.

\section{Summary}

This study was a cooperative effort by the Washington County Water Conservancy District and the U.S. Geological Survey to evaluate ground-water recharge beneath Sand Hollow Reservoir from September 2006 through December 2007. This study is an update to Heilweil and others (2005) and Heilweil and Susong (2007). Since its inception in 2002, diversions to Sand Hollow Reservoir from the nearby Virgin River generally have resulted in a rising reservoir altitude. Wet conditions during 2005-06 allowed the Washington County Water Conservancy District to fill Sand Hollow Reservoir to near capacity, thereby gradually increasing the surface area of the reservoir to about 1,300 acres during 2006. Drier and warmer conditions during 2007 resulted in less reservoir inflow and more evaporation, with the surface area of the reservoir decreasing to 1,044 acres by December 2007. After reaching a peak altitude of about 3,060 ft in May 2006, reservoir altitude declined to about 3,044 ft in December 2007, with surface-water storage declining from about 51,000 acre-ft

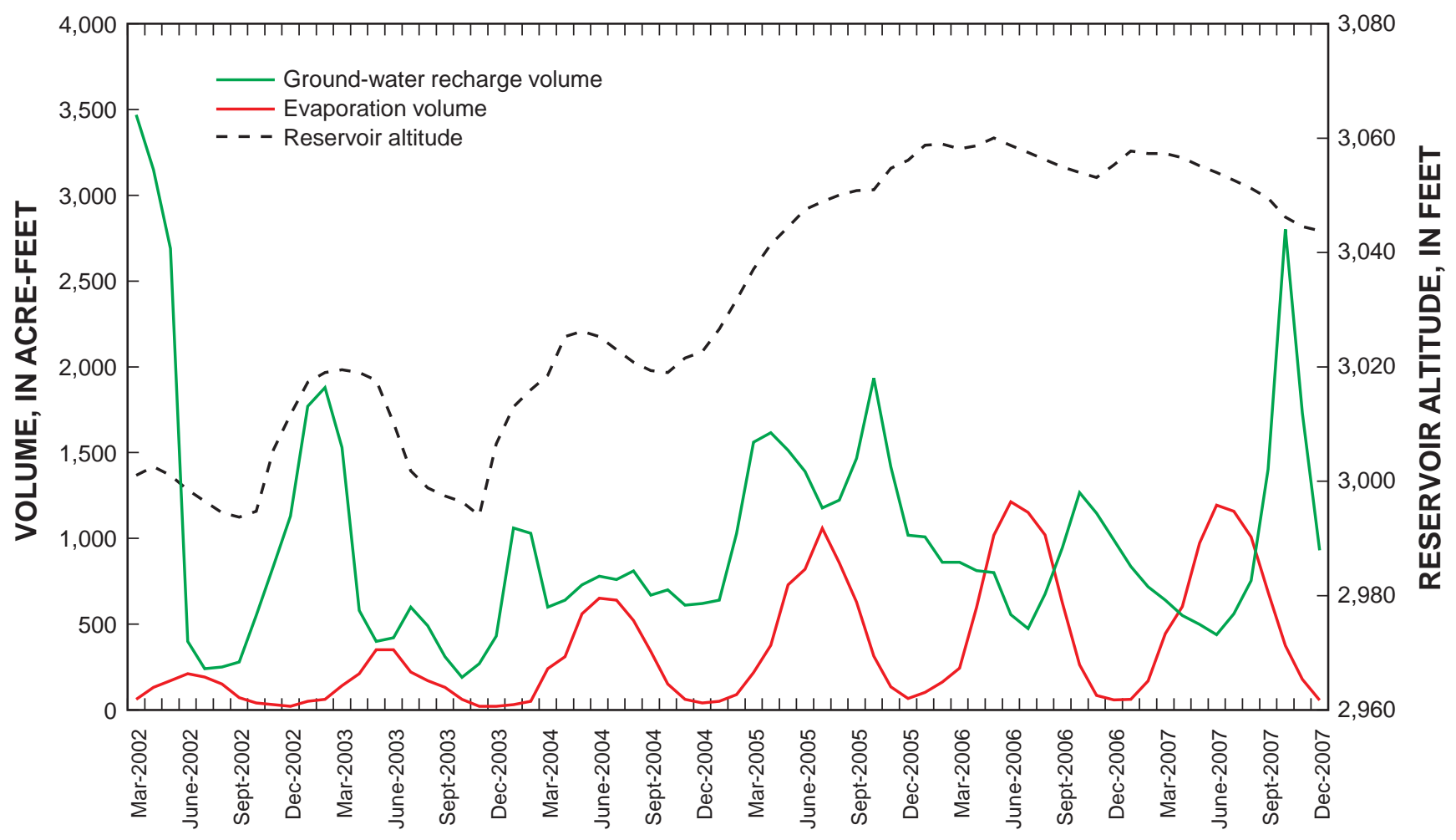

Figure 9. Monthly estimated evaporation, estimated ground-water recharge, and reservoir altitude, Sand Hollow Reservoir, Utah, March 2002 through December 2007. 


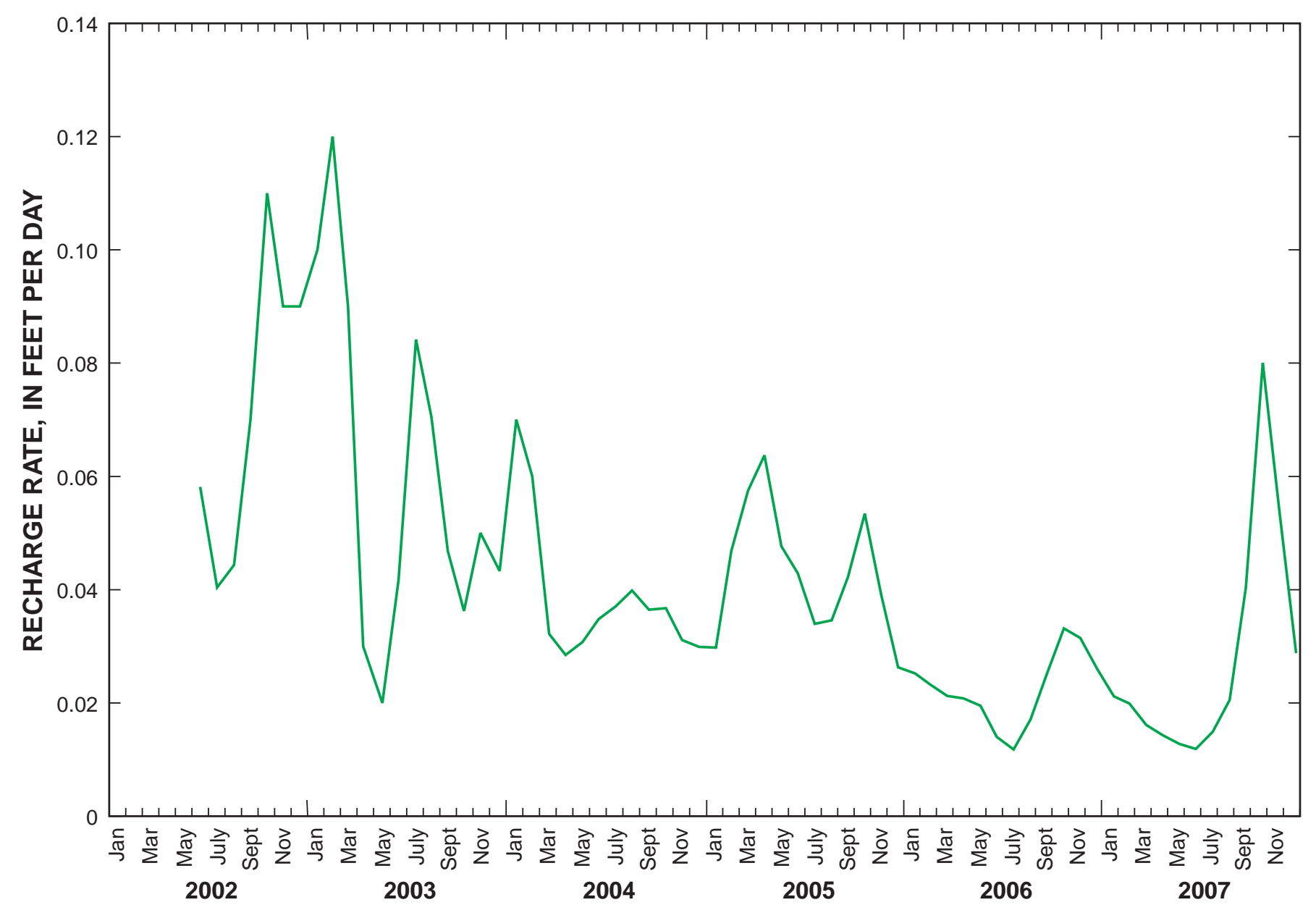

Figure 10. Monthly estimated ground-water recharge rate beneath Sand Hollow Reservoir, Utah, June 2002 through December 2007.

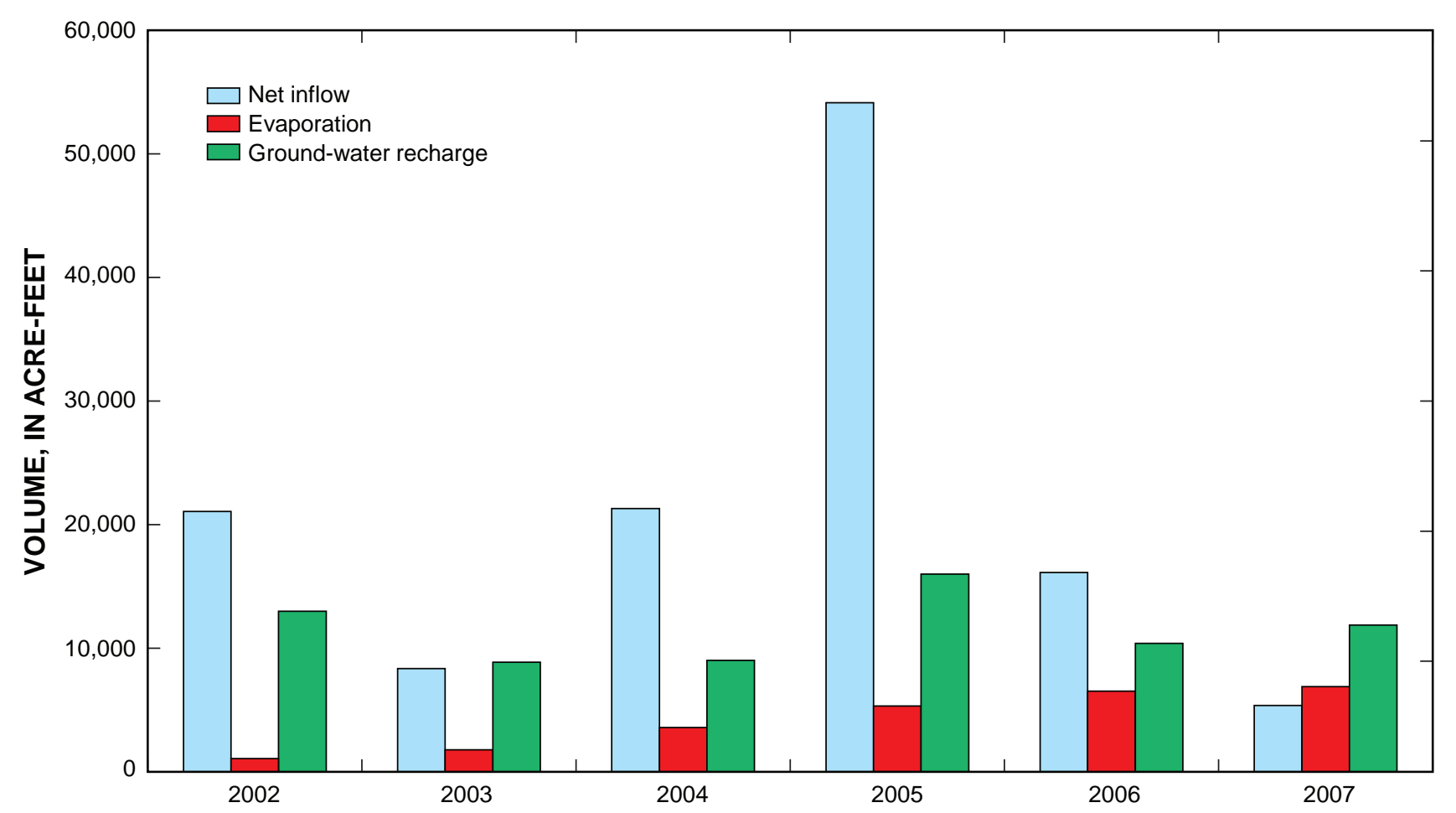

Figure 11. Annual inflow, estimated evaporation, and estimated ground-water recharge, Sand Hollow Reservoir, Utah, 2002-07. 
to about 32,000 acre-ft. Ground-water levels in monitoring wells in the basin during December 2007 ranged from about 6 to $76 \mathrm{ft}$ below land surface, or altitudes of 2,908 to 3,038 ft (6 to $136 \mathrm{ft}$ below the reservoir altitude of 3,044 ft). Since Sand Hollow Reservoir's inception in 2002, water temperatures at the surface of the reservoir ranged seasonally from about $3^{\circ} \mathrm{C}$ in the winter months to about $30^{\circ} \mathrm{C}$ in the summer months, whereas water temperatures deeper in the reservoir generally have risen to only about $28^{\circ} \mathrm{C}$.

Field-parameter measurements and chemical analysis of water samples from the reservoir and surrounding monitoring wells were used to evaluate changes in water quality and to assess the movement of managed aquifer recharge from the reservoir through the Navajo Sandstone aquifer. During the 2007 sampling, arsenic concentrations in monitoringwell samples ranged from 1.9 to $41.9 \mu \mathrm{g} / \mathrm{L}$; no Sand Hollow production wells used for water supply were sampled for arsenic during this study. The arsenic concentration in reservoir water remained low at $1.8 \mu \mathrm{g} / \mathrm{L}$. Arsenic concentrations in the 2-in. monitoring wells nearest the reservoir (sites 9, 36, and 37) increased after the inception of the reservoir, followed by a decrease in 2007 to concentrations similar to or less than pre-reservoir conditions. Changes in ground-water specific conductance, dissolved oxygen, total dissolved-gas pressure, $\mathrm{Cl}$, and $\mathrm{Cl} / \mathrm{Br}$ ratios since 2002 at sites 36 and 37 indicate the arrival of managed aquifer recharge. Contrasting peak arrival dates of these parameters at these wells, however, complicates the interpretation of both the arrival of managed aquifer recharge and the calculation of ground-water travel times. Additional tracers of managed aquifer recharge currently are being considered for future sampling to address this problem.

A water-budget approach was used to estimate groundwater recharge beneath Sand Hollow Reservoir, including surface-water inflow and outflow to and from the reservoir, evaporation, and changes in surface-water storage. Estimated monthly evaporation rates since the inception of the reservoir based on the Jensen-Haise Method have varied from 0.04 to $0.97 \mathrm{ft}$, resulting in monthly evaporation losses of 20 to 1,200 acre-ft. Total evaporation from March 2002 through December 2007 is estimated to have been about 25,000 acre-ft. Monthly recharge from September 2006 through December 2007 ranged from about 400 acre-ft to 2,800 acre-ft, totaling about 16,200 acre-ft. Since the inception of Sand Hollow Reservoir in March 2002, monthly recharge volumes have ranged from about 200 to 3,500 acre-ft through December 2007. Total recharge from March 2002 through December 2007 is estimated to have been about 69,000 acre-ft, with annual recharge ranging from about 9,000 to 16,000 acre-ft. An estimated recharge of almost 12,000 acre-ft during 2007 shows that the reservoir is still functioning according to its intended design for providing surface water for recreational activities, along with ground-water recharge to the underlying aquifer.

Estimated ground-water recharge rates, on the basis of monthly averages, ranged from 0.01 to $0.43 \mathrm{ft} / \mathrm{d}$, between March 2002 and December 2007. From March 2002 through the summer of 2007, there was a slight downward trend in recharge rates, even as reservoir altitude (driving head) increased. Superimposed on this trend are large seasonal fluctuations in recharge rates. Although the downward trend may be caused partly by lower hydraulic gradients as groundwater levels continue to rise, the causes of this trend and the seasonal fluctuations need to be investigated further.

\section{Acknowledgments}

The authors thank Josh Wright of Aqua Sports in St. George, Utah, for recovering a string of thermistors that contained reservoir water-temperature data from May 2006 through February 2007.

\section{References Cited}

Arthur, J.D., Dabous, A.A., and Cowart, J.B., 2002, Mobilization of arsenic and other trace elements during aquifer storage and recovery, Southwest Florida: U.S. Geological Survey Open-File Report 02-0089, p. 47-50.

Heilweil, V.M., Solomon, D.K., and Gardner, P.M., 2006, Borehole environmental tracers for evaluating net infiltration and recharge through desert bedrock: Vadose Zone Journal, v. 5, p. 98-120.

Heilweil, V.M., Solomon, D.K., Perkins, K.S., and Ellett, K.M., 2004, Gas-partitioning tracer test to quantify trapped gas during recharge: Ground Water, v. 42, no. 4, p. 589-600.

Heilweil, V.M. and Susong, D.D., 2007, Assessment of artificial recharge at Sand Hollow Reservoir, Washington County, Utah, updated to conditions through 2006: U.S. Geological Survey Scientific Investigations Report 20075023, $14 \mathrm{p}$.

Heilweil, V.M., Susong, D.D., Gardner, P.M., and Watt, D.E., 2005, Pre- and post-reservoir ground-water conditions and assessment of artificial recharge at Sand Hollow, Washington County, Utah, 1995-2005: U.S. Geological Survey Scientific Investigations Report 2005-5185, 74 p.

Hurlow, H.A., 1998, The geology of the central Virgin River basin, southwestern Utah, and its relation to ground-water conditions: State of Utah Water-Resources Bulletin 26, 53 p.

McGuinness, J.L. and Bordne, E.F., 1971, A comparison of lysimeter-derived potential evapotranspiration with computed values: U.S. Department of Agriculture Technical Bulletin 1472, Agricultural Research Service, Washington D.C., $71 \mathrm{p}$. 



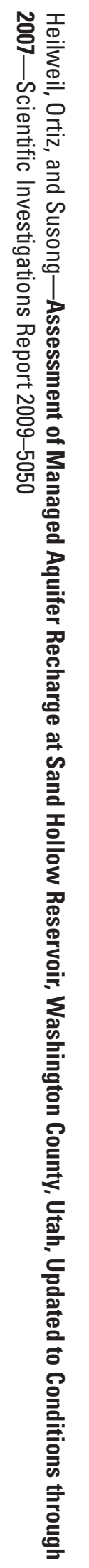

